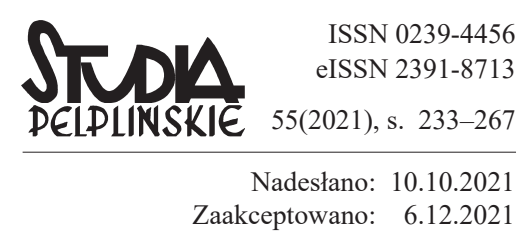

KS. JAN PERSZON

Uniwersytet Mikołaja Kopernika w Toruniu

pershing@umk.pl

ORCID: orcid.org/0000-0001-8331-6833

\title{
KASZUBSKIE PIELGRZYMOWANIE W XX WIEKU
}

DOI: http://dx.doi.org/10.12775/SPLP.2021.013

\section{Streszczenie}

Ruch pielgrzymkowy Kaszubów wpisuje się w kondycję człowieka, który znajduje się „w drodze”. Specyfika ruchu pielgrzymowania związana jest z istnieniem miejsc, gdzie znajdowały się cudowne wizerunki Matki Bożej. Zmiany społeczne, a także postęp technologiczny sprawił, iż zmienił się sposób pielgrzymowania, natomiast $\mathrm{w}$ zasięgu pielgrzymów zaistniały nowe miejsca. Postępująca współcześnie laicyzacja sprawia, iż zmniejsza się nasilenie ruchu pielgrzymkowego. Ogromną nadzieją jest jednak pobożność ludowa małych ojczyzn, sprawiająca, iż miejsca takie jak Sianowo, Swarzewo i Piaseczno są nadal licznie odwiedzane w czasie odpustów. Pielgrzymowanie jest kluczem do zrozumienia w ogóle polskiej religijności.

Słowa kluczowe: pielgrzymowanie, Kaszubi, Kościót, Matka Boża, Pomorze

\section{CASSUBIAN PILGRIMAGES IN THE 20TH CENTURY}

\begin{abstract}
The Cassubian pilgrimage movement corresponds with the human characteristic of being „on the way”. Its focal points are the Marian shrines with miraculous images. Due to the recent social and technological changes the way people participate in pilgrimages has evolved. More remote locations have become much more accessible. On the other hand, the laicisation phenomena have also taken their toll
\end{abstract}


and there are fewer participants than before. A new opportunity arose from popular piety of local communities such as Sianowo, Swarzewo and Piaseczno. There shrines are still popular among pilgrims during their patronal feasts. Undoubtedly, the pilgrimage movement is a key to understand the Polish religiousness as such.

\section{Keywords: pilgrimage, Cassubians, Church, Our Lady, Pomerania}

Niniejsze przedłożenie może być z oczywistych względów jedynie przyczynkarskie. Nie da się bowiem w jednym wykładzie adekwatnie ująć zagadnienia pątnictwa Kaszubów, które obejmuje kilka epok historycznych (okres zaboru niemieckiego do 1920 roku, 19 lat II Rzeczypospolitej, 5,5 roku niemieckiej okupacji i wojny, 45 lat panowania systemu komunistycznego i trzydziestolecia w III Rzeczypospolitej). Należałoby bowiem nie tylko opisać „aktywne” sanktuaria (ich działanie ewangelizacyjne i formacyjne, duszpasterzy, nabożeństwa, specyfikę) i związany z nimi ruch pielgrzymkowy (geografię pielgrzymek, ich przebieg, liczebność, program modlitewno-formacyjny), ale także kontekst społeczno-polityczny, w którym one funkcjonowały, a także potencjalne oddziaływanie pątnictwa na religijność i stan moralny społeczeństwa. W niniejszym wywodzie nie będzie też podejmowana refleksja natury ogólnej, odnosząca się do samej teologii miejsca świętego oraz postulatów pastoralnych, jakie Kościół katolicki pod adresem sanktuariów oraz ruchu pątniczego kieruje ${ }^{1}$.

Początki wędrowania Kaszubów do lokalnych sanktuariów maryjnych i pasyjnych trzeba wiązać z okresem baroku, zwanym też czasem kontrreformacji lub lepiej reformy katolickiej po Soborze Trydenckim (1545-1563). Zmaganie z protestantyzmem oraz rozkwit nowych zakonów (m.in. jezuitów) przydały dynamizmu pobożności katolickiej, która „wypowiadała się” m.in. w kulcie maryjnym i kalwaryjskim (pasyjnym). Jednym z przejawów tej pobożności było piesze pielgrzymowanie (indywidualne, rodzinne i nade wszystko parafialne oraz regionalne) do miejsc świętych. W wieku XVII w Rzeczypospolitej było 300 miejsc kultu maryjnego ${ }^{2}$. Okazją do pątnictwa (często wielodniowego) były, związane z przywilejami papieskimi, dni odpustowe. Niektóre sanktuaria, nie tyle z racji położenia, ile z powodu rosnącej popularności i famy, jakiej przydawały im cudowne znaki (zwłaszcza uznane za nadprzyrodzone uzdrowienia), nabierały znaczenia ponadre-

Zob. Kongregacja ds. Kultu Bożego i Dyscypliny Sakramentów, Dyrektorium o pobożności ludowej i liturgii. Zasady i wskazania, Poznań 2003, nr 261-287; por. A. Chelini, H. Branthomme, Drogi Boże. Historia pielgrzymek chrześcijańskich, Warszawa 1996.

2 Zob. A. Witkowska, The Cult of the Virgin Mary in Polish Religiousness from the 15th Century, w: The Common Christian Roots of the European Nations. An International Colloqium in the Vatican, t. 2, Florence 1982, s. 472. 


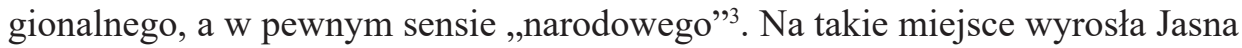
Góra, a nieco później Kalwaria Zebrzydowska. Kaszubskie i pomorskie sanktuaria pozostawały lokalnymi, co najwyżej regionalnymi miejscami świętymi. Co wcale nie znaczy, iżby Kaszubi (zapewne w znacznie mniejszej liczbie) nie wyprawiali się np. do Częstochowy. Godzi się wspomnieć, że już w połowie XVI wieku Grzegorz z Sambora, kanonik kościoła św. Anny w Krakowie, pisał:

Niewielka Częstochowa, ale wszystkie miasta

Całego świata swoim znaczeniem przerasta.

Tu nie tylko Polacy w święte mury spieszą

I Litwini pobożni gęstą idą rzeszą.

Tu mieszkańcy gór naszych i całe Polesie,

Kaszubi i lud Moskwy hołdy swoje niesie ${ }^{4}$.

Na Kaszubach w XX wieku mamy do czynienia z lokalnymi sanktuariami maryjnymi (Swarzewo, Sianowo, od roku 1970 Kościerzyna - formalnie, a od 1998 roku, czyli od koronacji wizerunku, faktycznie) i pasyjnymi (od połowy XVII wieku Wejherowo oraz od 1917 roku Wiele), do których pielgrzymowano z terenów przyległych. Znacznie rzadziej organizowano pielgrzymki wielodniowe (Pielgrzymka Kościerska do Wejherowa czy relatywnie „nowa”, zainicjowana w latach 80., pielgrzymka z Miastka do Sianowa), wymagające troski o noclegi i wyżywienie na trasie. Symboliczny jest udział Kaszubów w odpustach w Piasecznie; zaginął zaś zupełnie ruch pątniczy do Łąk Bratjańskich i do Matki Boskiej Bolesnej w Chełmnie nad Wisłą. W pamięci Kaszubów nie funkcjonuje już też,

3 Trzeba pamiętać, że przez wieki przez „naród” rozumiano wspólnotę obywateli, a więc najpierw szlachetnie urodzonych. Później - aczkolwiek nie bez oporów - do tej kategorii aspirowało bogatsze mieszczaństwo. Dopiero w XIX wieku kształtuje się - w oparciu o kryteria etniczne, językowe, religijne i kulturowe - pojęcie „narodu” jako wspólnoty kulturowej i terytorialnej. Na ukształtowanie się narodu polskiego znaczny wpływ miał czas zaborów oraz antypolska (a jednocześnie antykatolicka) polityka Rosji i Prus. Zob. Z. Zieliński, Kościól i naród w niewoli, Lublin 1995, s. 5-9. Na takie ponadregionalne i „narodowe” sanktuarium wyrosła - już w XV wieku - Jasna Góra. Od połowy wieku XVI - na fali zmagania z protestantyzmem, który kult Maryi zakwestionował - szybko wzrastała liczba pielgrzymów. 8 września 1650 r. - na odpust Narodzenia Matki Bożej - zgromadziło się 40 tys. pątników, zaś na jubileusz trzechsetlecia Jasnej Góry w 1682 r. aż 140 tys. Zob. Z. Bania, S. Kobielus, Jasna Góra, Warszawa 1983, s. 46-47.

4 Zob. Grzegorz z Sambora, Częstochowa poemat wydany w roku 1568 u Siebeneychera z tacińskiego na język polski, tłum. Wincenty Stroka, Kraków 1896, s. 29. Por. Z. Bania, S. Kobielus, Jasna Góra, s. 26. O Kaszubach, pielgrzymujących na Jasną Górę, pisał już w połowie XV wieku Jan Długosz, Historiae Polonicae, t. IV, Kraków 1873-1878, s. 399. Edmund Puzdrowski (Najświętsza Maryja Panna z Pomorza, s. 59) sądzi, że wzmianki Grzegorza z Sambora o pątnikach z Kaszub dotyczą przede wszystkim mieszkańców Pomorza Środkowego, które w XVI wieku stopniowo zdominowali protestanci. 
w XIX wieku i na początku XX chętnie nawiedzane, położone na krańcu regionu, sanktuarium w Trąbkach Wielkich ${ }^{5}$.

W minionym stuleciu, w dość ścisłej korelacji z czynnikami społeczno-politycznymi, pojawił się na Kaszubach nowy, poniekąd niespodziewany, impuls peregrynacyjny. W latach 70 . XX wieku niezwykłego dynamizmu nabrało, w dziejach pątnictwa niemające precedensu, piesze pielgrzymowanie Kaszubów i Pomorzan na Jasną Górę. Zrazu dokonywało się ono w ramach Pielgrzymki Warszawskiej, ale od 1979 roku już w Pielgrzymce Pomorskiej (toruńskiej), by za lat kilka ogarnąć szerokie rzesze młodzieży wędrującej w regionalnych, dobrze zorganizowanych grupach (chodzi zwłaszcza o Pielgrzymkę Kaszubską ze Swarzewa (od 1982) oraz Pielgrzymkę Kościerską (od 1991).

Osobnym fenomenem jest tzw. turystyka religijna, czyli zorganizowane pielgrzymowanie środkami transportu. Najpierw - bo na Pomorzu na szerszą skalę po roku 1870 - pojawiło się podróżowanie kolejowe. Zintensyfikowało się ono w połowie XX wieku. Z Kaszub udawano się koleją od lat 60. na Jasną Górę (co miało związek z Wielką Nowenną 1957-1966 przed Tysiącleciem Chrztu Polski), a nieco później pojawiła się możliwość pielgrzymowania autokarowego do sanktuariów krajowych i zagranicznych. W latach 80. i 90. pielgrzymowano w ten sposób do wielu, wcześniej niedostępnych, miejsc świętych (Wambierzyce, Bardo Śląskie, Ludźmierz, Kraków, Kalwaria Zebrzydowska, Gidle, Niepokalanów, św. Lipka, Gietrzwałd). Po roku 1990, wskutek rozpadu Związku Sowieckiego, uczęszczanym kierunkiem stała się Ostra Brama w Wilnie, po drodze nawiedzano zaś położone w Polsce wschodniej sanktuaria lokalne. W latach 90. stopniowo narastało używanie w podróżach do miejsc świętych samochodów osobowych. Na przełomie XX/XXI wieku udział ,pielgrzymów samochodowych” w sanktuaryjnych odpustach lokalnych (Swarzewo, Wejherowo, Sianowo, Wiele) urósł do imponujących rozmiarów. W latach 80 . XX wieku pojawia się, także nowe, wygenerowane przez rozwój technologiczny i wzrost zamożności mieszkańców, zjawisko pielgrzymek lotniczych, organizowanych przez diecezje, zgromadzenia zakonne i parafie, a nieco później także przez wyspecjalizowane firmy turystyczno-pielgrzymkowe. Celem pielgrzymek lotniczych był przede wszystkim - z racji na Jana Pawła II - Rzym. Po roku 1989 religijna turystyka lotnicza kierowała się też do Ziemi Świętej, Lourdes, Fatimy i leżącej w Meksyku Gwadelupy.

Jakub Fankidejski (Obrazy cudowne i miejsca, s. 129-133) stwierdza, że Matka Boska Trąbkowska czczona była przez cały wiek XVIII; w I połowie XIX wieku do tego sanktuarium pielgrzymowały liczne rzesze Kaszubów, przede wszystkim z Kościerzyny, która co roku przychodziła dziękować za ocalenie z pożaru. 


\section{MIEJSCA ŚWIĘTE NAWIEDZANE PRZEZ KASZUBÓW WXX WIEKU}

W II połowie XIX wieku Kaszubi licznie wędrowali nie tylko do Kaszubskiej Jerozolimy w Wejherowie, która bez wątpienia dzierżyła pierwszeństwo od końca XVII wieku. Wejherowska Kalwaria stała się dla Kaszubów miejscem wyjątkowym zwłaszcza pod koniec XIX wieku, gdy budziła nie tylko uczucia religijne, ale rozpalała polską samoświadomość pątników. Gromadząc co roku dziesiątki tysięcy wiernych, którzy modlili się i śpiewali w języku polskim, w wydatny sposób „przygotowała” Kaszubów na wolną Polskę, której czuli się synami i córkami ${ }^{6}$. Godzi się przypomnieć choćby o. Ambrożego Lewalskiego, który - jako jeden z ostatnich zakonników ze skasowanego przez Prusaków klasztoru reformatów w Wejherowie - przybywał na doroczne odpusty, by spowiadać i głosić budzące ducha narodowego kazania ${ }^{7}$. Sławny kustosz Kalwarii, ks. prałat Walenty Dąbrowski, właśnie na początku XX wieku zainicjował kazania w języku kaszubskim. Stąd zapewne nazywano go „królem Kaszubów”8. W Polsce międzywojennej Kalwaria stanowiła swoiste centrum pątnicze dla ludności kaszubskiej. Jak wspominają świadkowie, powojenne wznowienie wejherowskich odpustów spotkało się z nadzwyczajnym entuzjazmem wiernych. Przyczynił się do tego m.in. powrót dawnych opiekunów tego miejsca - franciszkanów-reformatów w roku $1946^{9}$.

6 Analogiczne procesy budzenia świadomości polskiej na Górnym Śląsku przez rozbudowany ruch pątniczy opisuje Jan Górecki, Pielgrzymki na Górnym Śląsu w latach 1869-1914, Katowice 1994, s. 11-16. Autor zauważa, że ruch pątniczy był jednym z elementów walki tak z nastrojami antykatolickimi w społeczeństwie (protestanci sprzymierzeni ze starokatolikami), jak i z uciskiem pruskim (zwłaszcza przez kulturkampf).

7 Zob. J. Walkusz, Kalwaria Wejherowska pod zarządem duchowieństwa diecezjalnego, s. 60-62; G .A. Kustusz, O. Ambroży Lewalski - duszpasterz i patriota, w: Wejherowo. Dzieje, kultura, środowisko. Materiaty z konferencji naukowej Wejherowo 28-29.05.1993 r., Wejherowo 1993, s. $179-188$.

8 Ks. Jan Walkusz (Kalwaria Wejherowska pod zarzadem duchowieństwa diecezjalnego, s. 64-67) stwierdza, że ks. Dąbrowski często kalwaryjskie kazania głosił po kaszubsku nie dla samej nobilitacji kaszubszczyzny, ale dla „zamaskowania ich treści” przed władzami pruskimi. Jako jedyny kapłan diecezji chełmińskiej miał zgodę Generalnego Wikariatu w Pelplinie na Słowo Boże po kaszubsku. Ponieważ miał wielki dar opowiadania i duże poczucie humoru, obdarzono go tytułem „króla Kaszubów”. Po kaszubsku głosił też kazania na Kalwarii - gdy władze zabroniły mu wygłaszać je po polsku - ks. Teofil Bączkowski z Mechowa, który rodowitym Kaszubą nie był.

9 Zob. A. R. Sikora, Droga do koronacji Obrazu Matki Bożej Wejherowskiej w zapisach Kroniki Wejherowskiego Klasztoru z lat 1946-1999, w: Kult Pani Ziemi Wejherowskiej w Duchowej Stolicy Kaszub. Materiały z sesji naukowej z okazji X-lecia koronacji obrazu Matki Bożej Wejherowskiej Wejherowo, 4 czerwca 2009, red. A. R. Sikora, Wejherowo 2010, s. 41. 
W dwóch głównych odpustach (Wniebowstąpienia i Trójcy Świętej) brały udział dziesiątki tysięcy wiernych ${ }^{10}$.

W II połowie XIX wieku Kaszubi dość licznie (okolice Bytowa, Kościerzyny, Kartuz, a nawet Lęborka) pielgrzymowali do Matki Boskiej Łąkowskiej. Sanktuarium to nazywano wtedy, ze względu na jego znaczenie i popularność, „pruską Częstochową". Długa wyprawa (w dwie strony przynajmniej trzy tygodnie) angażowała nie tylko pątników, ale wymagała towarzyszenia końskich zaprzęgów i orkiestry dętej. Kaszubskie pątnictwo do Łąk miało charakter ponadparafialny, pielgrzymi reprezentowali bowiem wiele wspólnot. Rozmach sanktuarium nadaliprzybyli tam w roku 1624 - franciszkanie. Szczyt sławy tego miejsca maryjnego przypadł na lata po koronacji papieskiej (1752), której dokonał biskup chełmiński Wojciech Leski. Na stulecie koronacji (1852) pielgrzymce gniewskiej, która zajmowała się organizacją pąci do Łąk, przewodził ks. Stanisław Kujot. Grupa liczyła około 3 tysięcy osób z Tucholi, Świecia, Śliwic, Lęborka, Kościerzyny, Kartuz, Ugoszczy i Gniewu ${ }^{11}$. Kaszubi wyruszali z Lęborka w I niedzielę po Zielonych Świątkach, po drodze dołączali pątnicy z okolic Bytowa i Kościerzyny. Boże Ciało pielgrzymi obchodzili w Pelplinie, a w sobotę, po tej uroczystości ruszali dalej. Po przeprawie przez Wisłę w Gniewie udawano się (przez Prabuty) do Łąk Bratjańskich, skąd - po spędzeniu tam kilku dni odpustowych - wracano do domu ${ }^{12}$. Ten kierunek pielgrzymowania ustał z racji kasaty przez władze pruskie klasztoru ojców reformatów w Łąkach Bratjańskich w roku 1875, czyli w dwa lata po tzw. ustawach majowych Sejmu Rzeszy ${ }^{13}$. O masowym udziale wiernych świeckich i duchowieństwa w dorocznych odpustach świadczy fakt, że w połowie XIX wieku uczestniczyło w nim od 20 do 30 tysięcy ludzi. Przez 10 dni trwania uroczystości (od Bożego Ciała do uroczystości) codziennie rozdawano 16 tys. komunii św., a posługę codziennie pełniło 24 spowiedników ${ }^{14}$. Po kasacie i pożarze klasztoru przyciągający tysiące pątników z całego Pomorza (ówczesna diecezja chełmińska,

10 Respondenci uczestniczyli jako dzieci w odpuście Wniebowstąpienia w latach 1947-1949. Zarówno w sobotę, gdy celebrowano obchody kalwaryjskie, jak i w odpustową niedzielę, Wejherowo było dosłownie oblegane przez tysiące przybyszów. Przed wyruszeniem procesji na obchody kalwaryjskie, cała wejherowska starówka była szczelnie wypełniona zgromadzonymi ludźmi. Inf. L. P. z Dąbrówki; Z. P., P. P. z Luzina; T. D z Szemuda; J. M. z Pomieczyna; B. K. z Barłomina.

11 Zob. A. Korecki, Sanktuarium Maryjne w Eakach Bratjańskich, Pelplin 2002, s. 36-37.

12 Według zapisu ks. Stanisława Kujota, który prowadził kompanię gniewską w 1872 r. (ok. 1500 osób), wędrowali w niej mieszkańcy wymienionych parafii i okolic. Zob. A. Korecki, Sanktuarium Maryjne w Eąkach Bratjańskich, s. 102-106.

13 Zob. A. Korecki, Sanktuarium Maryjne w Eąkach Bratjańskich, s. 72-79. 27 września 1875 r. proboszcz z Nowego Miasta ks. Jan Kloka, wygłosiwszy do ok. 1000 osób kazanie o prześladowaniu Kościoła, zabrał z kościoła łąkowskiego Najświętszy Sakrament, monstrancję i kielichy. Po usunięciu franciszkanów klasztor - aż do pożaru 5 maja 1882 r. - stał pusty. Uratowaną figurę MB Łąkowskiej przeniesiono do kościoła w Nowym Mieście.

14 Zob. A. Korecki, Sanktuarium Maryjne w Eakach Bratjańskich, s. 111-114. 
a wcześniej archidiakonat pomorski), Kurpiów oraz z katolickiej Warmii (ci katolicy, wędrując w osobnych kompaniach posługiwali się przeważnie językiem niemieckim) kult Matki Boskiej Łąkowskiej (dziś czczonej w kolegiacie w Nowym Mieście Lubawskim) podupadł i już nigdy nie został w tak masowej formie wznowiony ${ }^{15}$.

Kaszubi mieli nieco bliżej do położonego pod Gniewem Piaseczna. Choć brak potwierdzenia w archiwaliach, w XVIII wieku pielgrzymowali już do niego także Kaszubi. W czasie odpustu Narodzenia NMP spowiadało się wtedy od 6 do 7 tys. osób. W wieku XIX (do okresu kulturkampfu, czyli początku lat 70. XIX w.) przybywało około 20 tys. pątników (wszyscy pieszo lub furmankami, ponieważ linia kolejowa nie przebiegała przez Piaseczno). Później, wskutek dotkliwych represji, liczba uczestników znacząco zmalała, do około 10 tys. W okresie międzywojennym ,wielki odpust" gromadził - wedle wiarygodnych danych - nawet 50 tys. uczestników. Z Grudziądza, Torunia i Chełmna organizowano wtedy pielgrzymki drogą wodną, statkami wycieczkowymi na Wiśle. Już wtedy (np. w 1928 r. grupa z Osia) niektóre parafie przyjeżdżały do Piaseczna autobusami ${ }^{16}$. Regularnie do Piaseczna przybywała - co najmniej od lat 60. XX wieku - zorganizowana kompania pielgrzymkowa z Kościerzyny. Wydaje się jednak, że Piaseczno - tak przed, jak i po koronacji (8 września 1968 r.) - było i pozostaje centrum kultu maryjnego dla Kociewia i Borowiaków, w znacznie zaś mniejszym stopniu dla Kaszubów. Proporcji tych nie zmienia fakt, że do czasu budowy autostrady A1, w Piasecznie co roku regularnie zatrzymywały się na modlitwę i msze św. dziesiątki autokarów z pątnikami z Kaszub i Pomorza, udające się na Jasną Górę lub do innych miejsc $w$ Polsce centralnej i południowej.

W pierwszej połowie XX wieku małe Sianowo promieniowało tylko na najbliższą okolicę. Natomiast Swarzewo powoli - także z racji na swe położenie geograficzne - skupiało pątnictwo w wymiarze regionalnym. Niebagatelny wpływ na jego znaczenie i rozwój miała komunikacja kolejowa (na odpust Narodzenia NMP przed 1939 r. przybywali koleją mieszkańcy powstającej Gdyni, Redy, Rumi, Wejherowa, Gdańska i Luzina), później zaś - wędrujący dotąd pieszo - także rybacy i wczasowicze z Półwyspu Helskiego. Sam zaś pątniczy ruch pieszy ograniczał się do Wejherowa i kilku pobliskich parafii.

Warto zwrócić uwagę, że typowo „kaszubskie” współczesne maryjne centra pątnicze (Swarzewo, Sianowo) doświadczyły apogeum swej popularności względnie późno. Sanktuarium Królowej Polskiego Morza w Swarzewie - gruntownie

15 Zob. tamże, s. 102. Dwa lata po zamknięciu sanktuarium w Łąkach pelpliński „Pielgrzym” (z 8 września 1877) pisał, że Matka Boża „wyszukała sobie” na polskiej Warmii Gietrzwałd, który stał się celem „tłumnych pielgrzymek”. To nowe miejsce objawień stało się na wiele lat głównym sanktuarium dla Ziemi Lubawskiej.

16 J. Perszon, Piaseczno. Sanktuarium i ruch pątniczy w czasach wspótczesnych (XX i XXI wiek), s. 84 . 
opracowane w monografii Eugeniusza Pryczkowskiego - większego znaczenia nabrało na przełomie XIX i XX wieku. Z całą pewnością sanktuarium to było uczęszczanym miejscem już w wiekach wcześniejszych. Duże znaczenie miało już w wieku XVII; pątnicze grupy zorganizowane (pieszo i furmankami) przybywały do Swarzewa z Gdańska, Lęborka i Słupska. Liczba pątników rosła zwłaszcza w następstwie uroczystej koronacji cudownego wizerunku Madonny z Dzieciątkiem w roku 1937, by swe apogeum osiągnąć pod koniec minionego stulecia. Z kolei Sianowo, długo pozostając li tylko małym, lokalnym ośrodkiem kultu Maryi, zaczęło przyciągać wiernych w II połowie XIX wieku, rozkwitło zaś dopiero w II połowie XX wieku, stając się współcześnie najbardziej uczęszczanym sanktuarium na Kaszubach. Zorganizowane, parafialne i środowiskowe pielgrzymki piesze do Królowej Kaszub zaczęły się na dobre dopiero w roku „rewolucji Solidarności", czyli w $1980^{17}$. W ostatnich kilkunastu latach sanktuarium to przyćmiło (jeśli chodzi o rozmach uroczystości odpustowych i liczbę pielgrzymów) pozostałe sanktuaria kaszubskie. Liczbę uczestników lipcowego odpustu MB Szkaplerznej w ostatnich latach szacuje się na 15-25 tys. Oznacza to, że właśnie Sianowo wyrosło na nowe „duchowe centrum” Kaszub. Ten sam proces dostrzec można w relatywnie nowym miejscu świętym, jakim jest od 1917 roku Kalwaria Wielewska. Jej erekcja wywołała entuzjazm religijny mieszkańców Kaszub Południowych. Gasł on powoli w latach po II wojnie światowej, by rozkwitnąć w ostatnich kilkunastu latach, także za sprawą koronacji czczonego tu obrazu Maryi z Dzieciątkiem.

\section{EKLEZJALNE I SPOEECZNE UWARUNKOWANIA RUCHU PACTNICZEGO}

Życie i działanie Kościoła jest konsekwencją tajemnicy Wcielenia Syna Bożego i dzieła zbawczego, którego dokonał. Jezus Chrystus - aczkolwiek nie wprost, ale etapami - założył własną wspólnotę religijną, wyposażył ją w środki zbawienia (Słowo Boże i sakramenty) i w tym środowisku wiary pozostaje obecny. Ponieważ Kościół jest Ciałem Chrystusa, uobecnia Jego działanie i w pewnym sensie prze-

17 Wedle danych, które zebrał Eugeniusz Pryczkowski, pierwszą pieszą grupę pątniczą do Sianowa odnotowano na I rocznicę koronacji figury 10 września 1967 r. z Szymbarka. Później okazjonalnie przybywały pieszo (np. z Kartuz), grupy młodzieży organizował ks. E. Kupper. Zdecydowanie częściej przybywano autobusami, pieszo i rowerami. „Odpustową” pielgrzymkę zorganizował franciszkanin, o. Janusz Jędryszek z Lęborka wraz z działaczami ZKP w dniu 13 września 1980 r. W następnych latach pojawiły się kolejne piesze kompanie parafialne (Sierakowice, Linia, Strzepcz, Kartuzy, Prokowo), by - już w wolnej Polsce - rozszerzać się na kilkadziesiąt parafii. Zob. E. Pryczkowski, Swiónowsko nasza Matinko. Dzieje parafii i sanktuarium oraz cuda Królowej Kaszub, s. 259-260. 
dłuża misję Zbawiciela. Pozostaje jednak, w ziemskim wymiarze (Kościół pielgrzymujący) wspólnotą ludzką, ,zanurzoną” w historię, meandry systemów społecznych i politycznych, sytuację ekonomiczną i zmieniające się trendy kulturowe. Historyczne uwarunkowania silnie oddziałują (a nieraz wręcz je determinują) także na działalność sanktuariów oraz związany z nimi ruch pątniczy. W perspektywie wiary (ale także nauczania Kościoła) oba te fenomeny mają wymiar nie tylko społeczny i kulturowy, ale przede wszystkim religijny, czyli teologiczny. Są bowiem najpierw przejawem działania Bożego, a dopiero wtórnie owocem zaangażowania ludzi (wiernych świeckich i duchowieństwa). Stąd zasadne jest wpierw podjęcie refleksji nad „boską genealogią” kaszubskiego pielgrzymstwa, by następnie - choć jedynie fragmentarycznie - ukazać jego kontekst społeczny, polityczny i kulturowy.

\subsection{Boża (pneumatologiczna) geneza sanktuarium i ruchu pątniczego}

Motorem aktywności pątniczej, zrodzonej z głębokiej pobożności (wyprawa wymaga bowiem nie tylko kilku lub kilkunastodniowego marszu, związanego z wielu niewygodami, a często także nakładów finansowych) było (a poniekąd ciągle jest) przeświadczenie, że w sanktuarium działanie Boże (najczęściej przez Maryję czy innych świętych) jest w tajemniczy sposób intensywniejsze, mocniejsze, bardziej namacalne i skuteczne. Przez wieki Kościół troszczył się o sanktuaria, gościńce dla pątników, religijny charakter peregrynacji i poprawne rozumienie jej istoty. Niemniej sam zwyczaj udawania się (pieszo, konno, drogą morską, a od połowy XIX wieku także koleją) do miejsc świętych ciągle uchodził za formę pobożności ludu. Władze Kościoła wiedziały, że trzeba ją nadzorować, strzec przed wypaczeniami, na ile się da formować, ale pielgrzymka nigdy nie stała się w pełni instytucją eklezjalną ${ }^{18}$. Dłuższe pielgrzymowanie, zapewne z racji historycznych, często bywało kojarzone z włóczęgostwem i unikaniem obowiązków ${ }^{19}$. Pewne analogie zawiera anegdota: gdy w 1977 roku ówczesny wikariusz w Luzinie chciał się z kilkoma lektorami udać na pieszą Pielgrzymkę Warszawską, od swojego -

18 Salvador Ryan (Some Reflections on Theology and Popular Piety: a Fruitful or Fraught Relationship?, "The Heythrop Journal" 53(2012), s. 961-971) udowadnia, że podział na religijność elitarną (wysoką, uczoną, ortodoksyjną, poprawną teologicznie) i ludową (prostą, masową, wiejską, „skażoną” błędami i zabobonami) jest chybiony. Dlatego lepiej używać terminu „pobożność popularna” i „masowa”, który adekwatnie ujmuje zjawisko religijności znacznej większości danej populacji. Jej członkowie - we właściwy sobie i specyficzny sposób - religijnie „układają swe relacje ze światem nadprzyrodzonym”.

19 W religijnym średniowieczu dalekie pielgrzymki (np. do Composteli) zadawano jako pokutę złoczyńcom, w nadziei, że już do domu nie wrócą. Zob. H. Zaremska, Pielgrzymka jako kara za zabójstwo: Europa Środkowa XIII-XV w., w: Peregrinationes. Pielgrzymki w kulturze dawnej Europy, red. H. Manikowska, H. Zaremska, Warszawa 1995, s. 147-156. Piesze pielgrzymowanie jako karę za publiczne przestępstwa nakładano też na osoby koronowane. Zob. J. Sumption, Pilgrimage. An Image of Mediaeval Religion, Totowa 1976, s. 98-99. 
starszego już, ale bardzo gorliwego i rozgarniętego duchowo proboszcza - usłyszał: „po co"?

Dopiero pod koniec XX wieku, czyli w okresie pontyfikatu Jana Pawła II, pojawiła się próba teologicznego umocowania w doktrynie katolickiej zarówno sanktuarium, jak i ruchu pątniczego. Jan Paweł II, m.in. podczas poświęcenia Sanktuarium Miłosierdzia Bożego w Krakowie-Lagiewnikach (w sierpniu 2002) odpowiedział na pytanie, jak to się dzieje, że jedne miejsca święte zdobywają u wiernych „pierwszeństwo” przed innymi, a Kościół (w osobie biskupa miejsca lub papieża) ratyfikuje ten ich tajemniczy (nie dający się logicznie wythumaczyć) „wybór”. Wskazał na „zmysł wiary ludu Bożego” - sensus fidei, czyli tajemnicze działanie Ducha Świętego w sercach wierzących, który motywuje ich do uznawania jakiegoś miejsca (obrazu, figury, grobu świętego, krucyfiksu, kościoła) za szczególne i wybrane przez samego Boga ${ }^{20}$. Dopiero wtórnie pasterze Kościoła rozpoznają to działanie Ducha Świętego i podejmują kanoniczną decyzję o utworzeniu (erygowaniu) sanktuarium ${ }^{21}$. Analogiczny mechanizm wspólnotowego rozeznawania woli Bożej i posłuszeństwa wierze - bo do tego sprowadza się przecież dojrzewanie pewnych form pobożności ludowej - odegrał kluczową rolę np. w ostatecznym zatwierdzeniu w Kościele prawdy o wniebowzięciu Najświętszej Maryi Panny. Pius XII, po konsultacji z episkopatem świata, ogłosił ten dogmat - choć sama wiara (zwłaszcza w Kościele Wschodu) w tę prawdę trwała w Bożym ludzie nieprzerwanie - dopiero w 1950 roku $^{22}$. Podobny - choć trwający „tylko” dwanaście stuleci - proces obserwujemy w odniesieniu do klarowania się w Kościele prawdy o czyśćcu. „Dojrzewanie” czyśćca i jego teologiczna waloryzacja przez Kościół nastąpiły po wiekach modlitwy i wstawiennictwa za dusze zmarłych. Magisterium Kościoła przyjęło i doprecyzowało powszechną wiarę w „stan przejściowy”, czyli oczyszczenie po śmierci (purgatorium) dopiero

20 Por. J. Perszon, Kalwaria Wielewska jako nowe centrum kultu pasyjnego na Kaszubach, w: Kalwaria Wielewska. Stulecie trwania (1915-2015), red. B. Górczyńska-Przybyłowicz, F. Mudzo, M. Jania-Szczechowiak, Poznań 2017, s. 29-31.

21 Zob. J. Adamczyk, Szczególna przyczyna pobożności jako istotny warunek istnienia sanktuarium (kan. 1230). Aspekt kanoniczny, „Salvatoris Mater” 13(2011) nr 1-2, s. 230-246. Autor zwraca uwagę, że odnoszące się do pielgrzymujących do sanktuarium wyrażenie ob peculiarem pietatis causam (z powodu szczególnej przyczyny pobożności) odnosi się do egzystencjalnie, osobowo i duchowo „doświadczania” przez nich „przyciągania”. To zaś wzbudzane jest przez samego Boga, który jest głównym inspiratorem i twórcą sanktuarium. Pielgrzymowanie wiernych jest więc „odpowiedzią” na Bożą moc przyciągającą i promieniującą z sanktuarium. Por. Jan Paweł II, Redemptoris Mater, $\mathrm{nr} 28$.

${ }^{22}$ Konstytucję dogmatyczną Munificentissimus Deus Pius XII ogłosił nie w reakcji na jakąś herezję, ale z przekonania Kościoła, obecnego w sensus fidei, co do cielesnego wyniesienia Maryi do niebieskiej chwały. Zob. P. Beyga, Pobożność ludowa jako miejsce urzeczywistniania się sensus fidei na przykładzie dogmatu o wniebowzięciu Maryi Dziewicy, „Teologia w Polsce” 10,2 (2016), s. $165-175$. 
w połowie XIII wieku, przy okazji eliminując ekstrawagancje, fałszywe wyobrażenia czyśćca, błędy i nadużycia ${ }^{23}$.

Ten zmysł wiary wierzących jest zakorzeniony w charyzmacie prawdy (nieomylności i niezawodności), którego Chrystus udziela przez Ducha Świętego swemu Kościołowi, by ten w wierze nie zbłądził. Katechizm (889) stwierdza: „dla zachowania Kościoła w czystości wiary przekazanej przez apostołów sam Chrystus, który jest prawdą, zechciał udzielić swojemu Kościołowi uczestnictwa w swojej nieomylności”24. Katechizm (nr 92) naucza: „Ogół wiernych ... nie może zbłądzić w wierze i tę szczególną swoją właściwość ujawnia przez nadprzyrodzony zmysł wiary całego ludu, gdy 'poczynając od biskupów aż do ostatniego z wiernych świeckich' ujawnia on swą powszechną zgodność w sprawach wiary i obyczajów”. Dzięki mocy Ducha Świętego wierzący mogą wzrastać w rozumieniu tajemnic objawionych i doświadczanych spraw duchowych (Katechizm nr 94). Nieomylność całego Kościoła warunkuje więc zmysł wiary wiernych, czyli - jak stwierdza Marek Pyc - „duchową intuicję, wyrastającą z nadprzyrodzonej cnoty wiary.” Na mocy chrztu wierzący jest uzdolniony do intuicyjnego, doświadczanego i ,przedpojęciowego" poznania prawdy objawionej, do trwania w wierze i rozumienia tego, w co Kościół wierzy ${ }^{25}$. Międzynarodowa Komisja Teologiczna dodaje, że zmysł duchowy pozwala wierzącym - w ramach funkcji prorockiej - spontanicznie rozeznawać, czy dana nauka (i praktyka) jest zgodna z Ewangelią i wiarą apostolską, czy też nie ${ }^{26}$. Kardynał John H. Newman już w XIX wieku pisał, że sensus fidelium przejawia się raz przez enuncjacje episkopatu, kiedy indziej przez

${ }_{23}$ Zob. Z. Danielewicz, Traktat o rzeczywistości ostatecznej, w: M. Kowalczyk, Z. Danielewicz, Dogmatyka tom 6. Traktat o stworzeniu. Traktat o rzeczywistości ostatecznej, Warszawa 2007 s. 366-377.

24 Duch Święty nieustannie napełnia cały Kościół, mieszka w wierzących i jest Sprawcą oraz zasadą jedności eklezjalnej wspólnoty. On też rozdaje łaski i posługi, wyposaża Kościół w różne dary, czyli charyzmaty. Zob. Dekret o ekumenizmie ,, Unitatis redintegratio”, w: Sobór Watykański II, Konstytucje. Dekrety. Deklaracje, Poznań 2002, nr $2 .$.

25 Chodzi o bezpośrednią, intuitywną (a więc nie dającą się do końca skonceptualizować) zdolność rozpoznawania w jedności z Kościołem „spraw Bożych”. Ten „zmysł wiary” jest darem Ducha Świętego. Zob. M. Pyc, Pobożność ludowa a sensus fidei, „Studia Gnesnensia” t. XXVII (2013), s. 49-51. Leon Siwecki ('Sensus fidei' jako dar Ducha Świętego dla Kościoła, „Studia Theologica Varsoviensia” 43/1, 2005, s. 86) całość: 79-98) pisze: „Sensus fidei stanowi swoistą formę poznania osobowego, które poprzedza poznanie refleksyjne. Jest owocem wiary, łaski i Ducha Świętego, który działa w wierzących poprzez dary i charyzmaty. W ten sposób wierzący mogą lepiej poznawać i rozumieć prawdy wiary. Z mocy wiary człowiek otrzymuje zdolność, 'czujność', wrażliwość na rzeczy Boskie. Chodzi tutaj o swego rodzaju 'światło' i ukierunkowanie wobec wszystkiego, co należy do przedmiotu, przestrzeni wiary. [...]. Wierzący, który żyje intensywnie wiarą, nie tyle zauważa określoną, 'suchą' liczbę twierdzeń czy formuł intelektualnych, ile raczej spotyka się z żywą Nowiną, z Rzeczywistością, w którą wierzy. Św. Tomasz wyrazi to doskonale w stwierdzeniu: "Actus autem credentis non terminatur ad enuntiabile, sed ad rem"”.

26 Zob. Międzynarodowa Komisja Teologiczna, Sensus fidei w życiu Kościoła, thum. M. Moskal, Kraków 2015, nr 49. 
doktorów Kościoła i zwykłych wiernych; manifestuje się w liturgiach, zwyczajach i obrzędach, w wydarzeniach religijnych i ruchach, słowem - w całej historii ${ }^{27}$. Marek Pyc wnioskuje, że zmysł wiary jest - obok Pisma Świętego i Tradycji (oraz Magisterium Kościoła i teologii) - pierwotną instancją w rozeznawaniu i rozwoju wiary chrześcijańskiej ${ }^{28}$. Specyficznym „miejscem” przejawiania się zmysłu wiary Bożego ludu jest pobożność ludowa. Jest ona owocem działania Ducha Świętego. Wypływa z wiary Kościoła, w niej jest zakorzeniona i do niej (jako swej „normy”) winna się stosować. Sama jednak wielorako na tę wiarę oddziałuje i ją praktycznie wyraża ${ }^{29}$.

Józef Borzyszkowski, analizując przyczyny ,powodzenia”, czyli popularności pewnych miejsc świętych u wiernych, wyliczając aktywność ludzi (fundatorzy, organizatorzy, duszpasterze sanktuarium) używa określenia „siła tradycji”30. Pomorski historyk, objaśniając językiem naukowym tradycję jako ekwiwalent sensus fidelium dodaje, że ma na myśli ,,przekazywanie z pokolenia w pokolenie obyczajów, przekonań, zasad, wierzeń, sposobów myślenia, odczuwania, traktowania wydarzeń z przeszłości (niekiedy niesprawdzonych) jako historii, często wbrew nauce historycznej i zewnętrznej propagandzie"31. Uczony idzie śladami innego historyka, ks. Stanisława Kujota, który - podsumowując losy pomorskich sanktuariów w XIX wieku - decydującą rolę w ich zaistnieniu i rozwoju przypisał postawie wiernych świeckich. Ks. Kujot pisze: „Ile dojść można, żadne z przytoczonych tu miejsc nie nabrało sławy i rozgłosu przez księży; lecz wszystkie stały się cudownymi przez głos i wyrok wiernych świeckiego stanu"32. Ten ,zmysł wiary ludu Bożego" może się manifestować także przez bierny opór i sprzeciw. Tak było

27 Zob. P. Beyga, Pobożność ludowa jako miejsce urzeczywistniania się sensus fidei, s. 167-168.

28 Zob. M. Pyc, Pobożność ludowa a sensus fidei, s. 53-54. Teolog dodaje, że zmysł wiary podlega Magisterium, ale pozostaje samodzielny i nie może być wyprowadzany z Urzędu Nauczycielskiego Kościoła.

29 Zob. Kongregacja ds. Kultu Bożego i Dyscypliny Sakramentów, Dyrektorium o pobożności ludowej i liturgii, nr 61 .

30 Zob. J. Borzyszkowski, Sanktuaria maryjne Pomorza w diecezji chetmińskiej-legenda, tradycja i historia, w: tenże, Z dziejów Kościoła katolickiego na Kaszubach i Pomorzu w XIXi XX wieku, Gdańsk-Pelplin: Bernardinum 2000, s. 254-255.

31 Zob. J. Borzyszkowski, Sanktuaria maryjne Pomorza, s. 260. Autor dodaje, że w przypadku sanktuarium Matki Boskiej Nieustającej Pomocy w Toruniu (koronowanej w 1967 r.), jak i ustanowienie przez biskupa chełmińskiego (1983 r.) odbudowanej starej fary w Świeciu jako diecezjalnego sanktuarium Matki Boskiej Częstochowskiej nie sprawiło, iżby miejsca te stały się klasycznymi sanktuariami. Gdy zabraknie trwałej, silnej tradycji oraz opartego na niej ,ludowego" pątnictwa, miejsce święte pozostaje w pewien sposób ,jałowe”.

32 Pelpliński uczony dodaje, że w wielu przypadkach właśnie duchowni często sprzeciwiali się czci jakiegoś obrazu czy rzeźby, zwłaszcza poza murami własnego kościoła i bywali oporni w przyjmowaniu nadzwyczajnych wydarzeń (objawień, cudów). Zob. S. Kujot, Miejsca cudowne Najświętszej Maryi Panny w Prusach Królewskich (Dyecezya Chetmińska), w: Księga Pamiątkowa Maryańska ku czci pięćdziesięciolecia ogłoszenia dogmatu o Niepokalanym Poczęciu Najświętszej Mary Panny, Lwów 1905, s. 37, cyt. za: J. Borzyszkowski, Sanktuaria maryjne Pomorza, s. 261. 
w Sianowie. Gdy nowy - nieobeznany z lokalną tradycją proboszcz Józef Grünholz (od 1862 jako lokalny wikariusz, od 1865 proboszcz) - zabrał się za remont kościoła, usunął z ołtarza głównego czczoną od dawna Madonnę z Dzieciątkiem, a zastąpił ją większą (i w jego mniemaniu zapewne bardziej dostojną) figurą Maryi Niepokalanej, spotkał się ze zrazu „cichym”, później zaś także z formalnym i publicznym sprzeciwem wiernych świeckich. Przez kilka lat nie zważał na protesty i narzekania parafian i pątników. Dopiero interwencja chełmińskiej kurii biskupiej skłoniła go do odrestaurowania figury i umieszczenia jej w ołtarzu głównym w roku $1881^{33}$.

Podobną, „,teologiczną” sekwencję działań widzimy w odniesieniu do Swarzewa i Sianowa, gdzie pobożność ludu, rozpoznająca „nadzwyczajność” i nadprzyrodzoność oddziaływania figur Madonny z Dzieciątkiem, z biegiem czasu „wytworzyła" sanktuarium i ruch pątniczy. Ta sama prawidłowość wydaje się obowiązywać w przypadku, gdy „miejsce święte” zostało wymyślone i ufundowane przez wybitne osoby świeckie i duchowne. Tak przecież było z wojewodą malborskim Jakubem Wejherem, który dosłownie „od zera” założył w połowie XVII wieku kalwarię na wzgórzach okalających Nowe Miasto, czy z Kalwarią Wielewską, zbudowaną społecznym wysiłkiem licznych katolików świeckich z inspiracji ks. Józefa Szydzika. Warto zauważyć, że u genezy tych kaszubskich sanktuariów znajdujemy - czasem na poły legendarne - „cudowne” historie, które dla ludzi wiary są znakiem Nieba, nadprzyrodzoną interwencją „,domagającą się” odzewu ze strony ludzi. W przypadku Sianowa i Swarzewa są to zjawienia Matki Boskiej czyli mariofanie ${ }^{34}$, dla Wejherowa i Wiela tajemnicze natchnienia, nieodparta (choć bardzo trudna w realizacji) pewność, że fundowanie Kalwarii jest „wolą Bożą”35.

33 Zob. E. Pryczkowski, Swiónowsko nasza Matinko. Dzieje parafii i sanktuarium oraz cuda Królowej Kaszub, Banino 2016, s. 117-118.

34 Zob. E. Pryczkowski, Swiónowsko nasza Matinko, s. 55-59. Autor przytacza ludową tradycję o „wędrowaniu” figury między Mirachowem i Sianowem oraz zjawianiu się Madonny w krzaku paproci. Z kolei Madonna Swarzewska (E. Pryczkowski, Królowa Morza. Dzieje kaszubskiego sanktuarium Matki Boskiej Swarzewskiej, Swarzewo-Banino 2019, s. 50-51) została znaleziona przy źródle, a po przeniesieniu do kościoła w Helu ,wróciła”. Miała, po wyrzuceniu jej przez luterskich Helan - wedle jednej z wersji - zostać znaleziona nad brzegiem Zatoki Puckiej. Podobne opowiadanie legło u genezy sanktuarium maryjnego w Łąkach Bratjańskich. Zob. J. Fankidejski, Obrazy cudowne i miejsca w dzisiejszej diecezji chełmińskiej podtug urzędowych akt kościelnych i miejscowych podań, Gdynia 2011, s. 44-47.

35 Wojewoda Wejher budując Kalwarię powoływał się na ślub, który uczynił podczas walk pod Białą Smoleńską w 1634 r. Zob. J. Więckowiak, Kalwarie barokowe w Polsce, Gdańsk-Wejherowo 2006 s. 171-172; G. A. Kustusz, Święte Góry Wejherowskie, Gdynia 1991, s. 15-19. Franciszkanin uważa, że istotny wpływ na fundatora miał jego bliski współpracownik, archidiakon pomorski Jan Mateusz Judycki. O motywach, które powodowały ks. Józefem Szydzikiem, pisze Józef Borzyszkowski (Wielewskie Góry. Dzieje Wiela i jego kalwarii, Gdańsk 1986, s. 171-175). Wedle ks. Zdzisława Ossowskiego myśl zbudowania kalwarii zrodziła się już w 1905 r., gdy ks. Szydzik objął parafię w Wielu, a pobudką był fakt zwiedzania przez niego 
W następstwie znaków z nieba dane miejsce staje się ,świętą przestrzenią", sferą intensywnego działania Boga i doświadczania Jego obecnościci ${ }^{36}$. Ostateczną weryfikacją ,prawdy” tych przejawów-ingerencji sfery nadprzyrodzonej (czyli autentycznego zamysłu Bożego) jest - w obydwu przypadkach - oddziaływanie sanktuariów na kolejne pokolenia oraz ma ruch pątniczy.

Nie da się więc (choć niektórzy pewnie próbowali) „stworzyć” sanktuarium odgórnie, decyzją władzy eklezjalnej. Właśnie dlatego pewne sanktuaria zanikają, a inne nabierają duchowego znaczenia w ,geografii miejsc pielgrzymkowych”. $\mathrm{Z}$ tej perspektywy bardzo intrygującym przypadkiem jest np. Medjugorie, które - bez oficjalnego uznania tzw. objawień maryjnych (mariofanii) przez Kościół faktycznie stało się jednym z wiodących sanktuariów (centrów pielgrzymkowych) katolickiego świata ${ }^{37}$. Warto jednak pamiętać, że ostrożność pasterzy Kościoła w podejściu do tzw. objawień jest solidnie uzasadniona. Także w dziejach najnowszych (lata 80. XX wieku) mieliśmy w Polsce do czynienia (np. Oława na Śląsku, Okonin w Toruńskiem) z pseudo-objawieniami maryjnymi, które fascynowały tysiące gorliwych katolików. Wielu z nich pozostawało „głuchymi” na stanowisko Kościoła (biskupów miejsca), wzywające do powstrzymania się od łatwowiernej akceptacji rzekomych zjawisk nadprzyrodzonych ${ }^{38}$.

kalwarii w okolicach Monachium. Wedle innej wersji odwiedził go w Wielu kolega szkolny, natenczas ksiądz pracujący w Monachium. Podczas zwiedzania okolicy, pełen zachwytu miał stwierdzić, że są tu idealne warunki na budowę kalwarii. Gość przedstawił propozycję budowy kalwarii państwu Durajewskim, którzy zobowiązali się przekazać ziemię na ten cel. Wygłosił też w kościele kazanie, zachęcające parafian do tego ambitnego przedsięwzięcia. W liście (20 maja 1915 r.), w którym ks. Szydzik (który wcześniej jako wikariusz sam pielgrzymował do Wejherowa z Oliwy), gratulował ks. Walentemu Dąbrowskiemu godności kanonika, informuje go, iż ma zamiar budować kalwarię. Dodał, że jest urzeczony przykładem troski ks. Dąbrowskiego o Kalwarię Wejherowską. Pisał, że gdy jego parafianie usłyszeli o projekcie, wspominali, iż istnieje w Wielu dawna tradycja, że Jakub Wejher rozważał możliwość budowy kalwarii właśnie tutaj. O wyborze Wejherowa miała zdecydować płynąca tam rzeka Biała (czyli Cedron).

36 Zob. W. Łysiak, Święta przestrzeń. O pielgrzymkach, pielgrzymowaniu, miejscach pielgrzymkowych i pobożności ludowej w dawnym Księstwie Pomorskim, Poznań 2010, s. 13-24.

37 Por. J. Perszon, Trudności eklezjalnej recepcji objawień prywatnych, „Studia Koszalińsko-Kołobrzeskie”, 26(2019), s. 133-164; D. Rafalska, Medjugorie: prawda czy fatsz? Identyfikacja domniemanych ,objawień” z Medjugorie w świetle kryteriów teologiczno-psychologicznych, Lublin 2003; D. Szczerba, Sekret Medjugorie. Objawienia, historia, świadectwa, Kraków 2017.

38 O tych „objawieniach” pisze Hubert Czachowski, Cuda, wizjonerzy i pielgrzymi. Studium religijności mirakularnej końca XX wieku w Polsce, Warszawa 2003. Postawa entuzjazmu względem nowych „objawień” wyrasta z pobożności ludowej (masowej), która koncentruje się nie na ich obiektywnej ,prawdziwości”, ale na subiektywnym przekonaniu o tym, że Bóg realnie działa w świecie, interweniuje, jest najdosłowniej, „żywy”. Zob. J. Kumala, Fenomen zjawień maryjnych w przestrzeni pobożności ludowej, w: Wokót objawień maryjnych. Polskie pokłosie XXII Międzynarodowego Kongresu Mariologiczno-Maryjnego w Lourdes (4-8 IX 2008), red. T. Siudy, G. M. Bartosik, Częstochowa 2009, s. 108-109. 
Z tego misteryjnego (a ostatecznie pneumatologicznego) pochodzenia sanktuariów i ruchu pątniczego wynika, że to łaska Boża (co nie wyklucza aktywności człowieka) współdecyduje o powstaniu (rozwoju) lub słabnięciu (zaniku) danego „miejsca świętego". Stąd w ocenie znaczenia konkretnego sanktuarium i jego „statusu religijnego" trzeba zachować dystans, uwzględniający niebędący w ludzkiej mocy element działania Bożego.

\subsection{Czynniki społeczno-polityczne i ekonomiczne a ruch pątniczy}

Prawo rozwoju i zaniku sanktuariów dotyczy także tych, do których przez minione wieki wędrowali Kaszubi. Warto wskazać na czynniki pozareligijne, które istotnie wpływają na natężenie ruchu pątniczego, rozwój i znaczenie danego miejsca pielgrzymkowego, wreszcie na jego symboliczną oraz duchową „obecność" w religijności katolickiej. Wiele - jak dowodzi historia ostatnich dwóch wieków - zależy od czynników politycznych i społecznych. Na terenie dawnej diecezji chełmińskiej można tu wskazać na Łąki Bratjańskie, Chełmno n. Wisłą czy klasztor bernardynów z łaskami słynącą Matką Bożą w Świeciu. Wszystkie trzy miejsca zostały - za pomocą restrykcyjnych działań prawnych (kasaty zakonów) skazane przez władze pruskie bądź na kompletną anihilację, bądź na szczątkową wegetację. Ruch pątniczy - ale znacznie zredukowany - przetrwał w Łąkach i Chełmnie ${ }^{39}$; przepadł zaś definitywnie w przypadku Świecia ${ }^{40}$. Pruska kasata

39 Ks. Jakub Fankidejski (Obrazy cudowne i miejsca, s. 51-52) podaje, że kwitnący ruch pątniczy do Łąk Bratjańskich ustał wskutek usunięcia bernardynów (1875). Dzieła dokończył późniejszy pożar kościoła klasztornego w roku 1882. Zob. E. Piszcz, Łąki Bratjańskie-najstarsze miejsce kultu maryjnego w diecezji chetmińskiej, „Nasza Przeszłość”, t. XXXIV, Kraków 1971, s 177-203. O dziejach i ruchu pątniczym do cudownego obrazu NMP Bolesnej w Chełmnie zob. J. Fankidejski, Obrazy cudowne i miejsca, s. 52-70; P. Roszak, S. Tykarski, Popular Piety and Devotion to Parish Patrons in Poland and Spain, 1948-1998, ,Religions” 2020,11,658. Do Chełmna na odpust Nawiedzenia Najświętszej Maryi Panny 2 lipca w roku 1882 pielgrzymowało ok. 10 tys. ludzi („Pielgrzym” 76 (7 lipca 1882), s. 2-3. W 1922 r. odnotowano pielgrzymki z Brus, Łęga, Czerska i Borów Tucholskich („Nadwiślanin” 42 (9 lipca 1922, s. 2), zaś w 1932 r. w liczbie ok. 20 tys. pątników odnotowano grupy z Torunia, Tczewa, Pucka i Gdyni (Kalendarz Kościelny dla Parafji Chetmińskiej na rok Pański 1933, s. 26). Część pątników z Torunia, Grudziądza i Tczewa przybywała łodziami i statkami po Wiśle. W 1997 r. sanktuarium miało już tylko charakter lokalny; przybyło 6 pielgrzymek z okolicznych parafii w liczbie ok. 1 tys. osób. Zob. „Głos” 62(1997) s. 4.

40 Jakub Fankidejski (Obrazy cudowne i miejsca, s. 108-109) przywołuje podanie o wojewodzie pruskim i staroście świeckim Janie Jabłonowskim, który w 1624 r. miał napisać pieśni o obrazie Matki Bożej, czczonej w bernardyńskim kościele w Świeciu. Sam obraz (którego obecność działała cuda) miał pochodzić z Gdańska, zakupiony od luteranina przez pobożnego szlachcica spod Sandomierza. Tymczasem Jabłonowscy byli w Świeciu znacznie później, pieśń powstała najpewniej w 1724 r. Zob. E. Puzdrowski, Najświętsza Maryja Panna z Pomorza w poezji i pieśni, „Studia Pelplińskie” t. XVII (1986), s. 61. Jak podaje Krzysztof Koch (Świecie, EK 19, kol. 363-364) w 1624 r. zbudowano kościół pod wezwaniem Niepokalanego Poczęcia Najświętszej Maryi Panny, a dla obsługi cudownego obrazu i ruchu pątniczego klasztor bernardyński. Kasata 
zakonów dotknęła także Kalwarię Wejherowską; represje kulturkampfu osłabiły ruch pątniczy do Swarzewa, ale w obydwu wypadkach tak determinacja wiernych, jak zmiany polityczne (odrodzenie Rzeczypospolitej) przyczyniły się do odzyskania znaczenia przez te sanktuaria ${ }^{41}$.

Istotne znaczenie - zwłaszcza od II połowy XIX wieku - dla prosperowania sanktuariów (nie tylko w Polsce) mają szlaki komunikacyjne (przede wszystkim kolejowe), czyli łatwość/trudność dotarcia do miejsc świętych. Przez wieki do miejsc świętych podróżowano pieszo lub konno. Wyprawy dalsze np. z Anglii do Rzymu czy Composteli, były możliwe dzięki komunikacji morskiej. Parafialne czy regionalne kompanie posługiwały się wozami czyli zaprzęgami konnymi, które przewoziły bagaże, osoby kontuzjowane, a często starszych pątników, którzy na dłuższy marsz nie mieli już sił. Jeszcze w latach 70. XX wieku w kaszubskich pielgrzymkach do Swarzewa i Wejherowa kryte wozy (platformy) konne służyły pątnikom ${ }^{42}$. Właśnie w wieku XIX (choć nie tylko dzięki kolei) notujemy szybki wzrost liczby pielgrzymów w Częstochowie, a nieco później także w Kalwarii Zebrzydowskiej ${ }^{43}$. Co do pielgrzymek z Pomorza i Kaszub do tych miejsc dane

klasztoru (1816) przyczyniła się do upadku sanktuarium; sam zaś obraz Matki Bożej Świeckiej spłonął w 1902 r. Sporządzenie kopii obrazu i ustanowienie w dawnym klasztorze parafii nie przyczyniło się do odnowienia wcześniejszego kultu.

${ }^{41}$ W Wejherowie znakomite zasługi położył w tym zakresie najpierw ks. prałat Walenty Dąbrowski, który opiekował się kalwarią w latach 1887-1924, później zaś ks. Edmund Roszczynialski. W Swarzewie wielkie zasługi położył budowniczy nowego, neogotyckiego kościoła ks. Józef Gollnik. Później (w latach 1910-1939) kustoszem sanktuarium był ks. Wojciech Pronobis. Przez lata aktywność patriotyczną w Swarzewie wspierał o. Ambroży Lewalski. Zob. E. Pryczkowski, Królowa Morza. Dzieje kaszubskiego sanktuarium Matki Boskiej Swarzewskiej, s. 94-95.

42 Autor przez kilka lat uczestniczył w pielgrzymce z Luzina do Swarzewa. Liczącej ok. 200 osób grupie towarzyszyło kilka dwukonnych wozów do przewozu (za drobną opłatą) bagażów. Jeden z nich wiózł osoby starsze, które nie szły pieszo, ale w drodze odmawiały różaniec i śpiewały pieśni. Osobny wóz służył tzw. orkiestrze dętej; kapela (od 5 do 10 osób) grała bowiem tylko na niektórych odcinkach drogi. „Idący” z pielgrzymką ksiądz miał do dyspozycji bryczkę, z której korzystał zależnie od kondycji fizycznej.

43 Z Wielkiego Księstwa Poznańskiego - tak ze względu na odległość, jak i rosyjskie przepisy paszportowe, do Częstochowy pielgrzymowano w XIX wieku (poza Poznaniem) sporadycznie i w małych liczbach. Dopiero od roku 1876, gdy ukończono tzw. linię kluczborską (a ostatecznie od 1903, gdy kolej dochodziła do Częstochowy) pątnicy z północnej części zaboru pruskiego mieli dogodne połączenie. Zob. S.Z. Jabłoński, Jasna Góra ośrodek kultu maryjnego (1864-1914), Lublin 1984, s. 165-170; Z. Zieliński, Wielkopolskie pielgrzymki na Jasną Górę w czasie niewoli narodowej, „Studia Claramontana” 1(1981), s. 101-102. Uruchomienie linii kolejowej wzmogło też ruch do Kalwarii Zebrzydowskiej. Zob. H. E. Wyczawski, Kalwaria Zebrzydowska. Historia klasztoru bernardynów i kalwaryjskich dróżek, Kalwaria Zebrzydowska 1987, s. 216. Sanktuarium to w wieku (druga połowa wieku XIX), kiedy rocznie pielgrzymowało tam między 300 a 350 tys. ludzi, po koronacji Matki Bożej Kalwaryjskiej (1887) wyrastało na ogólnopolskie i międzynarodowe. Zob. I. Sołjan, Kalwaria Zebrzydowska na tle innych ośrodków w Karpatach Polskich, „Peregrinus Cracoviensis” z. 2, 1995, s. 78-79. 
są bardzo skąpe ${ }^{44}$. Dopiero na przełomie XIX i XX wieku pojawiają się pielgrzymki stanowe i zawodowe na Jasną Górę. Okazją do prawdziwie ogólnonarodowych pielgrzymek (co już w wolnej Polsce stanie się tradycją) było pięćsetlecie Jasnej Góry (8.09.1882), poświęcenie wieży jasnogórskiej (15.08.1906), powtórna koronacja Ikony (22.05.1910) oraz poświęcenie drogi krzyżowej $(29.08 .1913)^{45}$. Z kolejowych przejazdów przez wiele lat korzystało Wejherowo z jego kalwarią, oraz nieco mniej Swarzewo, ale w tym samym czasie rozwijały położone na uboczu Sianowo czy Wiele. Nie da się tedy sformułować jednoznacznych komunikacyjnych determinantów określających ,popyt” i ,podaż” w zakresie miejsc pątniczych oraz tendencji ich rozwoju. Nie ulega jednak wątpliwości, że komunikacja kolejowa (później zaś autokarowa i samochodowa) przyczyniła się (wraz z duszpasterską strategią kard. Augusta Hlonda, a potem kard. Stefana Wyszyńskiego) do bezprecedensowego wzrostu znaczenia Jasnej Góry ${ }^{46}$. Lata Wielkiej Nowenny zmobilizowały także dziesiątki tysięcy Kaszubów do podróży-pielgrzymek kolejowych do Częstochowy i wytworzenia ,legendy" tego - dotąd z autopsji znanego tylko nielicznym - sanktuarium. Mieliśmy faktycznie do czynienia z upowszechnioną turystyką religijną; niemniej motywy tego ,pielgrzymowania” oraz jego owoce były w najczystszej postaci religijne ${ }^{47}$. Począwszy od lat 60 . XX wieku niemal wszystkie parafie na Kaszubach i Pomorzu zaczęły organizować doroczne wyjazdy na Jasną Górę. Jak się zdaje, apogeum natężenia tej formy pielgrzymowania przypadło na dwudziestolecie 1965-1985 ${ }^{48}$. Pokłosiem ekspansji/popularyzacji tamtej - po części zaaranżowanej przez Prymasa Tysiąclecia - „duchowej

44 Zob. S. Z. Jabłoński, Jasna Góra, s. 170-171. W 1892 r. odnotowano grupy Gniazd Sokolich (a więc młodzieży) z Chełmży, Grudziądza i Pelplina.

45 Zob. tamże, s. 257.

46 W roku 1932, na 550-lecie sanktuarium Jasną Górę odwiedziło ponad milion pielgrzymów. W II Rzeczypospolitej promocja Jasnej Góry była jednym z priorytetów episkopatu Polski. W latach 30. wprowadzono nową formę czci Maryi Jasnogórskiej przez ślubowania poszczególnych stanów: kobiet, mężczyzn, młodzieży akademickiej, nauczycieli. Zob. M. Janus, P. Nowak, Piesze pielgrzymowanie, s. 40-41.

47 Ks. Prymas pisał (10.11.1955) z Komańczy do generała paulinów: „Bodaj nigdy tak dobitnie jak teraz nie uświadomiłem sobie tego, jak potężna jest wola Boża, by Jasna Góra była Stolicą Chwały Bożej, która rozlewa się na Polskę przez dziewicze dłonie Pośredniczki łask wszelkich. Bodaj nigdy jak teraz nie widziałem tego tak jasno, że wolą Ojca Narodów jest, by naród polski był zjednoczony przez Jasną Górę i by tutaj się odnawiał i krzepił. Tej woli Bożej nikt nie zdoła złamać, o czym świadczą wieki naszego trwania na Jasnej Górze, bardziej jeszcze niezłomnego niż mury i wały obronne.” Zob. S. Wyszyński, Wielka Nowenna Tysiaclecia, Paris1962, s. 10.

48 Zbadanie zasięgu tych pielgrzymek oraz ich liczebności wymagałoby zweryfikowania źródeł jasnogórskich oraz dziesiątków archiwów parafialnych (tzw. ogłoszeń parafialnych). W parafii św. Wawrzyńca w Luzinie regularne (doroczne) pielgrzymki kolejowe zaczęły się w roku Ślubów Jasnogórskich, czyli 1956. Większe parafialne grupy pątników (na przełomie lat 70/80) udawały się na Jasną Górę w rocznicę nawiedzenia kopii Ikony Jasnogórskiej (17-18 listopada 1960); liczyły one od 100 do nawet 300 osób. Zob. J. Perszon, Vir Fidelis. Ksiądz Mieczysław Sumiński. Proboszcz w Luzinie i dziekan wejherowski, Pelplin 2017, s. 189-190. 
Stolicy Polski” był (od końca lat 70. XX wieku) nieznany wcześniej rozkwit pielgrzymek pieszych młodzieży na Jasną Górę ${ }^{49}$.

Dla ruchu pątniczego istotne znaczenie miała sytuacja polityczna. Nie od rzeczy będzie wspomnieć o trwającym na Pomorzu od połowy XVI wieku napięciu/ zmaganiu międzywyznaniowym, czyli konflikcie i koegzystencji katolicyzmu z protestantyzmem. Z jednej strony konflikt ten „napędzał” katolicką pobożność maryjną i samo pątnictwo (oba zjawiska zostały przez protestantyzm zakwestionowane), $z$ drugiej sanktuaria i pielgrzymowanie umacniały katolicką (w pewnym sensie także polską - zwłaszcza pod koniec XIX wieku) tożsamość wiernych i rozwijały masową (ludową) pobożność. W trwaniu przy katolicyzmie „przechowała się" i umacniała więź z polskością (polski język modlitwy, nauczania religii, pieśni, spowiedzi, kazań), także z tej racji, że Pomorze i Kaszuby przez cały czas zaborów (ku zmartwieniu pruskiego zaborcy) należały do „polskiej” metropolii gnieźnieńskiej ${ }^{50}$. Argumentu tego nie unieważnia fakt, że Kościół rzymski (zwłaszcza jego duchowni) na Kaszubach był w tym czasie dwujęzyczny i spora część księży i wiernych świeckich reprezentowała kulturę niemiecką ${ }^{51}$. Istotną rolę w rozbudzaniu w Kaszubach polskości pełnili patriotycznie nastawieni duchowni, pasterzujący w sanktuariach ${ }^{52}$. Duże znaczenie miał też polski ruch wydawniczy, skupiony zwłaszcza w Pelplinie, choć z natury rzeczy skoncentrowany na rozwoju religijności: modlitewnikach, katechizmach, śpiewnikach. Ogromną rolę spełnił wydawany w stolicy diecezji chełmińskiej „Pielgrzym”, abonowany przez kilka tysięcy mieszkańców miast i wsi ${ }^{53}$. W II połowie XIX wieku Pelplin (dzięki wybit-

49 Prym w II połowie XX wieku ma Pielgrzymka Warszawska. Gwałtowny „przybór” liczby pątników nastąpił w latach 70. XX wieku. W 1978 r. szło w niej 30 tys. osób; w 197938 tys.; w 1982 49 tys.; w 198353500 pątników. W roku 1979 pod hasłem: „Niesiemy pomoc Ojcu Świętemu” przyszło na Jasną Górę 120 pieszych pielgrzymek. Tym samym nastała epoka regionalnych (diecezjalnych) pielgrzymek idących promieniście na Jasną Górę. Łączna liczba pieszych pątników wyniosła ok. 150 tys. osób. Zob. Cz. Ryszka, Idzie wierna Warszawa. 300 lat Warszawskiej Pielgrzymki Pieszej, Częstochowa-Warszawa 2010, s. 260-279.

50 Z. Zieliński, Kościót i naród w niewoli, s. 33-37.

51 Zob. tamże, s. 41. Jak dodaje Józef Borzyszkowski (Pelplin jako ośrodek życia kulturalnego na Pomorzu w XIX i XX wieku, w: tenże, Z dziejów Kościoła katolickiego na Kaszubach i Pomorzu w XIX i XX wieku, Gdańsk-Pelplin 2000, s. 132-135; prawie 1/3 katolików w diecezji chełmińskiej była niemieckojęzyczna.

52 Zob. J. Borzyszkowski, Sanktuaria maryjne Pomorza, 255-256. Historyk przywołuje wybitnych duchownych, którzy walnie przyczynili się do rozwoju sanktuariów: ks. Jana Szmaka z Chełmna, ks. Mariana S. Stojanowskiego z Piaseczna (XVII wiek), ks. Jana M. Doeringa ze Swarzewa (który w 1684 r. zlecił namalowanie obrazu-historii sanktuarium).

53 Zob. J. Borzyszkowski, Pelplin jako ośrodek życia kulturalnego na Pomorzu w XIX i XX wieku, s. 140-145. W 1868 r. Stanisław Roman założył w Pelplinie drukarnię i wydawnictwo, on też zapoczątkował nowe pismo „Pielgrzym”, wydawane w latach 1869-1939. Nakładem „Pielgrzyma" ukazały się setki druków: modlitewników, śpiewników, statutów towarzystw świeckich, zbiorów kazań, listów biskupów, żywotów świętych, pomocy katechetycznych, katechizmów 
nym uczonym, Collegium Marianum, wydawnictwom i organizacjom ziemiańskim) stał się pomorskim centrum kultury polskiej.

Dopiero w następstwie kulturkampfu można mówić o polaryzacji i konflikcie „polskiego” (kaszubskiego) katolicyzmu z Niemcami (faworyzującymi protestantyzm). Podziały te - jak się zdaje - nie były aż tak proste i klarowne. Niemniej stanowiły czynnik wzmagający kaszubskie pielgrzymstwo ${ }^{54}$. Owo przeciwstawienie „swój”, czyli Polak i katolik oraz „obcy” - potencjalnie groźny Niemiec, potwierdziło się w strasznych realiach wojny i okupacji lat 1939-1945 ${ }^{55}$.

Nieco później „obcym” duchowo i kulturowo stał się każdy, kto uosabiał system komunistyczny ${ }^{56}$. Na ten podział nakładały się zarówno antykatolicka, ideologiczna walka systemu wierzącego w materializm dialektyczny, państwowa promocja ateizmu (tzw. naukowego światopoglądu), obsadzanie niemal wszystkich stanowisk publicznych (szkoła, wojsko, media, administracja centralna i lokalna, policja - wówczas Milicja Obywatelska, tajne służby (Urząd Bezpieczeństwa Publicznego, później Służba Bezpieczeństwa), sądownictwo, przedsiębiorstwa

i elementarzy. Oficyna wydawała też pisma dla rolników i gospodyń, kalendarze. Wydawnictwa „Pielgrzyma” oddziaływały też na Warmię.

54 Z. Zieliński (Kościót i naród w niewoli, s. 19-48) stereotyp Polak-katolik (który jego zdaniem nie jest bynajmniej tylko mitem) sytuuje w kontekście dziejów Rzeczypospolitej, w której Polak (w odróżnieniu od Rusinów) niemal zawsze oznaczał łacińskiego katolika. Zbitkę tę utwierdził i zradykalizował czas zaborów, zwłaszcza w zaborze rosyjskim i pruskim. Historyk zauważa, że np. w diecezji chełmińskiej (ale także na Górnym Śląsku, Warmii i Powiślu) znaczna część duchowieństwa i administracji kościelnej była w wieku XIX zgermanizowana. Dopiero podczas kulturkampfu, który wcale nie był elementem antypolskiej polityki rządu pruskiego, nastąpiło „przebudzenie" polskie u wielu duchownych. Por. też L. Trzeciakowski, Kulturkampf w zaborze pruskim, Poznań 1970; A. Rogalski, Kościót katolicki na Warmii i Mazurach, Warszawa 1956; A. Rogalski, Kościót katolicki na Ślasku, Warszawa 1955; A. Mańkowski, Pod rządami pruskimi (1815-1846, 1846-1871, 1871-1918), „Roczniki Historyczne” 3:1927, s. 255-323.

55 O straszliwych i programowych (zaplanowanych) prześladowaniach polskości i wiary katolickiej, zastosowanych przez hitlerowskie Niemcy w diecezji chełmińskiej (eksterminacja połowy duchowieństwa, likwidacja polskiej inteligencji) piszą m.in.: J. Walkusz, $W$ cieniu połamanego krzyża. Studia i szkice z dziejów Kościoła katolickiego na Pomorzu Nadwiślańskim w latach 1939-1945, Tczew-Pelplin 1999; J. Sziling, Polityka okupanta hitlerowskiego wobec Kościoła katolickiego 1939-1945, Poznań 1970; Z. Zieliński, Religia w narodowosocjalistycznej koncepcji spoleczeństwa, w: Życie religijne w Polsce pod okupacja hitlerowska 1939-1945, red. Z. Zieliński, Warszawa 1982, s. 11-37.

56 O ile od 1918 stereotyp Polak-katolik był narzędziem gry politycznej (prawdziwy Polak to katolik), o tyle po II wojnie światowej motyw Polak-katolik został - zwłaszcza w nauczaniu kard. Stefana Wyszyńskiego - znacząco przekształcony. W jego „teologii Narodu” punktem ciężkości nie był już nacjonalistyczny ekskluzywizm, ale konsekwentny, żywy katolicyzm, stanowiący siłę służącą Narodowi w zachowaniu jego tożsamości. Zob. Z. Zieliński, Kościót i naród w niewoli, s. 26-30. Por. też S. Wyszyński, Kościót w stużbie Narodu, Rzym 1981; Cz. S. Bartnik, Chrześcijańska nauka o narodzie wedtug prymasa Stefana Wyszyńskiego, Lublin 1982; R. Iwan, Prawa, obowiązki i zagrożenia narodu wedtug prymasa Stefana Wyszyńskiego, Lublin 1989; J. Lewandowski, Naród w nauczaniu kardynała Stefana Wyszyńskiego, Warszawa 1982. 
państwowe i spółdzielcze - przez ludzi lojalnych względem władzy, a często wobec lokalnych wspólnot wyobcowanych. Godzi się dodać, że życie Kościoła i jego personel (zwłaszcza duchowieństwo) praktycznie od roku 1945 aż do schyłku PRL objęte było profesjonalną inwigilacją i działaniami destrukcyjnymi, prowadzonymi przez tajne służby państwa ${ }^{57}$. Władze PRL konsekwentnie i z użyciem wszelkich dostępnych środków dążyły do ateizacji społeczeństwa. Nawet podejmowane w latach 70. (tzw. epoka E. Gierka) jak i 80. (po stanie wojennym z grudnia 1981 r.) pozory dialogu (czy współpracy) z Kościołem oznaczały jedynie zmianę oficjalnej taktyki. Cel pozostawał ten sam: przejąć z rąk Kościoła „rząd dusz”, by na gruzach chrześcijaństwa zbudować „nowe społeczeństwo” - socjalistyczne. Systemowa dyskryminacja katolicyzmu (w mniejszym zaś stopniu innych wyznań i religii) bardzo mocno dotykała ruchu pielgrzymkowego. O ile komuniści godzili się na kult ograniczony do tzw. przysłowiowej „kruchty”, o tyle wszelkimi sposobami zwalczali jakiekolwiek przejawy życia religijnego w przestrzeni publicznej. A ponieważ dysponowali totalitarnymi środkami (pełna kontrola nad wszystkimi instytucjami państwa oraz dysponowanie olbrzymią częścią majątku narodowego), opór Kościoła - jedynej instytucji względem państwa autonomicznej - mógł być jedynie bierny ${ }^{58}$. Terror (czasem stopniowany) był bowiem inherentną cechą komunizmu ${ }^{59}$. Świadom tego był prymas Stefan Wyszyński, który - broniąc praw Kościoła i narodu - nastawiał się na „przetrwanie" ${ }^{60}$. W niejako „oczywisty” dla siebie sposób władze nie tylko kontrolowały (inwigilowały) tradycyjny ruch pielgrzymkowy, ale stopniowo go ograniczały. Chodziło bowiem o jego całkowita likwidację. Nakładane na organizatorów pielgrzymek pieszych, kolejowych i autokarowych (pod byle pozorem) sankcje powodowały, że aż do lat 60 . XX wieku np. w Pielgrzymce Warszawskiej dominowali ludzie starsi. Dopiero

57 Por. W. Polak, Materiały Stużby Bezpieczeństwa zwiazane z inwigilacją uroczystości odpustowych w Sanktuarium Maryjnym w Piasecznie, w: Diecezja chetmińska w czasach komunizmu (19451990), red. W. Polak, W. Rozynkowski, J. Sziling, Pelplin 2009, s. 305-356; D. Gucewicz, Władze PRL wobec sanktuarium w Piasecznie, w: Kultura materialna i duchowa sanktuarium $w$ Piasecznie, red. W. Pikor, Pelplin 2018, s. 117-147. Por. też: J. Żaryn, Kościół a władza w Polsce (1945-1950), Warszawa 1997; L. Potykanowicz-Suda, Państwo a Kościót katolicki w województwie gdańskim w latach 1945-1970, Warszawa 2011.

58 Władze komunistyczne do 1948 r. stwarzały pozory współpracy z Kościołem. Później, z małymi przerwami w czasie tzw. odwilży (1956/1957; 1971; 1980-1981), kontynuowały walkę ideologiczną, której celem było stworzenie nowego, wyzwolonego z tradycji i religii, człowieka. Zob. J. Żaryn, Kościól a władza w Polsce (1945-1950), Warszawa 1997; J. Żaryn, Dzieje Kościoła katolickiego w Polsce (1944-1989), Warszawa 2003.

59 Zob. B. Wildstein (Odpowiedzialność Marksa, w: tenże, O kulturze i rewolucji, Warszawa 2018, s. 131) stwierdza, że rządy krajów bloku sowieckiego „Terror jako metodę rządzenia stosowały samodzielnie - choć we współpracy i pod osłoną Moskwy - aby utrzymać się u władzy i obronić system, którego celem było zasadnicze przeobrażenie istniejącej cywilizacji i zamieszkującego ją człowieka. W inny sposób komunizm nigdy i nigdzie nie potrafił zapewnić sobie panowania.".

60 Zob. S. Wyszyński, Zapiski więzienne, Warszawa 1995, s. 18. 
później „długodystansowe” pątnictwo stało się popularne wśród młodzieży. Istotny wpływ na taki stan rzeczy miało rozwijane półlegalnie duszpasterstwo młodzieży, przede wszystkim ruch Światło-Życie ${ }^{61}$. Podnoszony dziś przez środowiska lewicowe i anarchistyczne postulat „wypchnięcia” religii z życia społecznego i zamknięcia jej w ramach wąsko rozumianej prywatności jest więc nową $\mathrm{w}$ formie, ale tożsamą w treści, kontynuacją (choć inaczej uzasadnianą) strategii komunistów ${ }^{62}$.

Po 1989 kategorie te w znacznej mierze się zdezaktualizowały, choć bywają wskrzeszane przez straszenie „liberałami” i - najzupełniej realnymi - lewicowymi, antychrześcijańskimi ideologiami postmoderny. Dominacja „nowej kultury”, której nieodłącznym elementem jest posunięta do anarchii „wolność” od wszelkiej tradycji, sprawia, że - przynajmniej od jakiegoś czasu - pobożne nawiedzanie sanktuariów (przede wszystkim w miastach) znów stało się formą kontrkultury ${ }^{63}$. Ewidentnym symptomem ,postępu” dechrystianizacji i porzucania szeroko pojętej tradycji - co jest uwarunkowane przez zmianę mentalności młodzieży i dorosłych (do 40. roku życia) - jest malejąca liczba pątników, udających się na doroczne odpusty do Wejherowa i Swarzewa ${ }^{64}$. Proces ten - wedle oceny kustoszów - nie jest jeszcze widoczny w odniesieniu do Sianowa i Wiela. Może to mieć związek ze strukturą ekonomiczno-społeczną subregionów, z których rekrutują się udający się do tych sanktuariów pątnicy ${ }^{65}$. Wydaje się jednak, że zachodzące tam procesy społeczne, obserwowane przez socjologów kultury w skali ogólnokrajowej (i na całym Zachodzie) są tylko - dzięki sile wiejskiej (parafialnej) tradycji - spowol-

${ }_{61}$ Zob. T. P. Terlikowski, Franciszek Blachnicki. Ksiadz, który zmienit Polskę, Kraków 2021; D. Seweryn, Nasze korzenie. Wspomnienia i świadectwo, Kraków 2019.

62 Projekt całkowitego zerwania z tradycją i dotychczasową kulturą (utożsamiany z absolutną wolnością od natury, prawdy, jakichkolwiek ograniczeń) jest realizowany bez użycia terroru. Zob. B. Wildstein, Międzymorze, w: tenże, O Kulturze i rewolucji, s. 247; Ch. Delsol, Nienawiść do świata. Totalitaryzmy i ponowoczesność, Warszawa 2017, s. 13-14.

${ }^{63}$ O podłożu ideologicznym faktycznego „zerwania z tradycją” przez elity (środowiska kształtujące tzw. opinię publiczną) na przełomie XX/XXI wieku w imię neomarksistowskiej rewolucji, mającej ostatecznie wyzwolić człowieka (od historii, natury, religii, sumienia i norm kulturowych), zob. B. Wildstein, Bunt i afirmacja. Esej o naszych czasach, Warszawa 2020. Postmodernistyczny projekt ,nowego świata” i ,nowego człowieka” analizuje francuska myślicielka. Zob. Ch. Delsol, Nienawiść do świata. Totalitaryzmy i ponowoczesność.

${ }^{64}$ Inf. ks. S. Majkowski ze Swarzewa; ojcowie: R. Nikel, F. Nowak, F. Szymański, M. Janus z Wejherowa.

${ }^{65}$ Inf. ks. J. Flisikowski z Wiela, ks. J. Ostrowski z Lipusza, ks. A. Bączkowski z Kościerzyny, ks. A. Kubisz z Dziemian, ks. E. Grzędzicki z Sianowa, E. Pryczkowski z Banina, ks. Cz. Las z Żukowa, ks. W. Mielewczyk z Przodkowa. Na „,wielki odpust” Wniebowstąpienia Pańskiego do Wiela przybywa od 10 do 15 tys. osób; do Sianowa (odpust MB Szkaplerznej) od 15 do 20 tys. Por. J. Perszon, Pobożność pielgrzymkowa Kaszubów. Tradycja i współczesność, w: Pelpliński Areopag. Religijność Pomorza, red. Ł. Grzędzicki, J. Szulist, Gdańsk 2016, s. 60. E. Pryczkowski (Swiónowsko nasza Matinko, s. 277-282) podaje, że łączna liczba nawiedzających Sianowo (pieszo, w grupach autokarowych, rowerowych, pielgrzymkach biegowych) wynosi od 35 do 45 tys. pątników. 
nione. Zmiany w podejściu do tradycji religijnej są w Polsce w ostatnich kilkunastu latach gwałtowne. Ich skutkiem jest niespotykana dotąd laicyzacja mentalności i zwyczajów sporego odsetka młodzieży ${ }^{66}$.

Wszystko to nasuwa wniosek, że pielgrzymowanie i prosperowanie sanktuariów (co ma istotny związek z żywą wiarą i dążeniem do świętości) jest w dużym stopniu uwarunkowane tendencjami kulturowymi, modami intelektualnymi, a schodząc głębiej - podzielaną przez znaczną część (większość) społeczeństwa wizją człowieka (antropologią).

\subsection{Sanktuariotwórcza rola duchowieństwa i fundatorów}

Osobnym czynnikiem, który kształtował kaszubskie pielgrzymowanie w wieku XX i wcześniej, była aktywność (lub jej brak) kustoszów/gospodarzy sanktuariów oraz biskupów, którzy nierzadko z wielkim zaangażowaniem promowali ruch pątniczy (tak było m.in. z zaangażowaniem biskupów kujawskich w odniesieniu do Piaseczna) ${ }^{67}$. Jakub Wejher zaprosił do opieki nad powstającą Kalwarią Franciszkanów-Reformatów, którzy w wieku XVII i XVIII walnie przyczynili się do rekatolicyzacji okolicznej ludności, a pośrednio także do umocnienia jej polskości ${ }^{68}$. Później bywało różnie, ale Kalwaria i tłumiony przez Prusy ruch pątniczy odżyły za czasów proboszczowania kilku kapłanów diecezjalnych, wśród nich ks. prał. Walentego Dąbrowskiego ${ }^{69}$. Ten ostatni został - decyzją biskupa Leona

${ }^{66}$ W bardzo adekwatny sposób gwałtowny „odpływ” młodych z Kościoła (nauka religii, praktyki religijne, udział w życiu parafii, deklaracja wiary lub niewiary) opisują Agnieszka Łoza i Paweł Beyga, Zaraza w Kościele, Wydawnictwo Leksem Studio: Żmigród 2021. W zakresie systemu wartości u średniego i młodego pokolenia na Kaszubach brak aktualnych i pogłębionych badań. Poczynione przez autora (Lipusz 2016) badania młodzieży gimnazjalnej wykazały, że niemal w całości jest ona użytkownikiem sieci. Przeciętny (dzienny) czas spędzony przy komputerze (gry, filmiki, czat, muzyka itd.) oscylował między 3 a 4 godz.

${ }^{67}$ Recz dotyczy wszystkich sanktuariów na Kaszubach, które do 1821 roku należały do Archidiakonatu Pomorskiego diecezji kujawskiej (włocławskiej), później zaś - do 1992 r. - do powiększonej diecezji chełmińskiej ze stolicą w Pelplinie. Podział tej diecezji (dokonany bullą Jana Pawła II Totus tuus Poloniae populus z 1992 r.) wpłynął niewątpliwie na ruch pielgrzymkowy. Widać to m.in. w Wejherowie, które od kilkunastu lat odnotowuje spadek liczby pątników z Kościerzyny i Kartuz. Znamienne, że ruch pątniczy do Sianowa z kaszubskich terenów archidiecezji gdańskiej na zmianach granic diecezji nie ucierpiał.

68 Zob. G.A. Kustusz, Święte Góry Wejherowskie, s. 27-28.

69 Zob. J. Walkusz, Kalwaria Wejherowska pod zarzadem duchowieństwa diecezjalnego, w: Kult Matki Bożej na Kaszubach i Pomorzu. Studia nad kultura religijna Kaszubów i Pomorzan. Materiały z sympozjum mariologicznego w Wejherowie 17-18 maja 1999 r., red. G.A. Kustusz, B.J. Soiński, Wejherowo 1999: Urząd Miasta Wejherowa i Prowincja św. Franciszka z Asyżu Zakonu Braci Mniejszych - Franciszkanów, s. 136-146. Historyk pisze o ustawodawstwie kulturkampfu (1 kwietnia 1873 franciszkanie zostali usunięci z klasztoru, zaś 31 maja 1875 r. całkowicie skasowano wejherowski konwent), które w zamiarach zaborcy miało zminimalizować oddziaływanie kalwarii. Ks. Jan Rook, proboszcz św. Trójcy (1861-1887) od 1875 stał się faktycznym, troskliwym i zaradnym opiekunem kalwarii i pątników. Wykonał kapitalny remont 
Rednera i kolatora hrabiego Keyserlingka - proboszczem parafii Trójcy Świętej w Wejherowie. Jako Kaszuba pochodzący z pobliskiego Gowina z wielką energią zabiegał o utrzymanie tradycji pielgrzymek. Przez 38 lat witał i żegnał osobiście pątnicze kompanie. Wielką wagę przywiązywał do posługi pielgrzymów, zwłaszcza do kaznodziejstwa ${ }^{70}$. Jego następca, ks. prałat Edmund Roszczynialski (proboszcz w Wejherowie w latach 1924-1939) znakomicie wyczuwał „kaszubskiego ducha”, z ogromną energią rozwijając ruch pielgrzymkowy i troszcząc się o perłę duchowości lokalnej - kalwarię $e^{71}$.

Ten sam zakon franciszkański co w Wejherowie rozwijał aż do kasaty kult Matki Bożej Łąkowskiej w Ziemi Lubawskiej. Zdarzało się, że duchowni, którzy oprócz zapału i wizji rozwoju powierzonego im miejsca świętego, odznaczali się też konsekwencją (i szczęściem) w jej realizacji. Ich gorliwość promieniowała na całą okolicę, zapalając do pielgrzymowania lokalne społeczności. Taką rolę można np. przypisać przedwojennemu kustoszowi Piaseczna ks. Augustynowi Bukoltowi ${ }^{72}$, oraz wybitnemu proboszczowi tej parafii, niedawno zmarłemu ks. drowi Kazimierzowi Myszkowskiemu ${ }^{73}$. Sianowo wiele zawdzięcza ks. Aleksandrowi Kaźniakowi, który doprowadził do papieskiej koronacji Figur Jezusa i Maryi, ale także obecnemu kustoszowi ks. Eugeniuszowi Grzędzickiemu, który kult Królowej Kaszub roztropnie moderuje i pomnaża ${ }^{74}$. Bez wytrwałości i wizjonerstwa ks. Józefa Szydzika nie byłoby kalwarii w Wielu, a tym samym wielkiego ducho-

wszystkich kaplic kalwaryjskich. O jego zasługach zob. też G.A. Kustusz, Święte Góry Wejherowskie, s. 102-103.

70 Zob. J. Walkusz, Kalwaria Wejherowska pod zarządem duchowieństwa diecezjalnego, w: tenże, Kościół na drogach pomorskiej przeszłości. Studia i szkice z XIX i XX wieku, Lublin 2014, s. 60-61.

71 Ks. Roszczynialski pochodził z pobliskich Łężyc, był więc od dziecka z Kalwarią mocno związany. Od 1920 r. pracował jako katecheta w Seminarium Nauczycielskim w Wejherowie. Zob. J. Walkusz, Kalwaria wejherowska pod zarzadem duchowieństwa diecezjalnego, s. 70-80.

72 Ks. Augustyn Bukolt (1873-1939) ukończył Collegium Marianum w Pelplinie i gimnazjum chełmińskie. Po święceniach w Pelplinie (1.04.1899) był wikariuszem w Toruniu (Parafia NMP), w Grążawach i Kurzętniku, Chełmnie, Kijewie i Radzyniu. Od 1920 r. do męczeńskiej śmierci w listopadzie 1939 r. był proboszczem w Piasecznie. Rozwinął odpustową oktawę Narodzenia NMP, zabiegał o popularyzację kultu MB Piaseczyńskiej. W latach 20 i 30. Liczbę pątników na odpustową niedzielę szacowano na 15-20 tys. (relacje „Pielgrzyma”). W odpuście regularnie brali udział pątnicy zza Wisły (Ziemia Sztumska), dawniej należącej do diecezji chełmińskiej. Zob. H. Mross, Bukolt Augustyn, w: tenże, Stownik biograficzny kapłanów diecezji chetmińskiej wyświęconych w latach 1821-1920, Pelplin 1995, s. 27. O odpustach i ich organizacji zob. J. Perszon, Piaseczno. Sanktuarium i ruch pątniczy w czasach wspótczesnych (XX i XXI wiek), s. $78-86$.

73 Tamże, s. 90-91.

74 Zob. E. Pryczkowski, Swiónowsko nasza Matinko. Dzieje parafii i sanktuarium oraz cuda Królowej Kaszub, s. 300-301. 
wego dobra, które dzięki niej stało się południowym Kaszubom ${ }^{75}$. Bez determinacji ks. Zygmunta Trelli z Mechowa nie byłoby pewnie Kaszubskiej Pielgrzymki Pieszej ze Swarzewa na Jasną Górę, która zaczęła się w roku $1982^{76}$. Jednak powodzenie jego inicjatywy ziściło się tylko dlatego, że ówczesna młodzież na Kaszubach odpowiedziała na nią entuzjastycznie i masowo. To zaś uznać można za przejaw sensus fidelium, czyli nadprzyrodzonego zmysłu wiary ${ }^{77}$.

W wielu miejscach - zresztą wzorem średniowiecza - ważną rolę w promocji i podtrzymywaniu życia pątniczego w sanktuarium odgrywa katolicki laikat. Można wskazać choćby Bractwo św. Krzyża w Kościerzynie, Bractwo Szkaplerzne w Piasecznie czy rolę Zrzeszenia Kaszubsko-Pomorskiego w najnowszych dziejach sanktuarium w Sianowie ${ }^{78}$.

Tzw. czynnik ludzki jest więc jednym z najważniejszych dynamizmów w szeroko pojętym ruchu peregrynacyjnym. Gdy twierdzimy, że ruch pątniczy jest dziełem Bożej łaski, musimy od razu dodać, że Boże działanie urzeczywistnia się przez ludzi. Także tych, którzy z Bogiem walczą. Surowe restrykcje, jakie w II połowie XIX wieku zastosowała carska Rosja wobec ruchu pątniczego na Jasną Górę, praktycznie „odcięły” Wielkopolskę (Księstwo Poznańskie) Śląsk i Pomorze (od bulli De salute animarum z roku 1821 niemal całe Pomorze, czyli

75 Zob. J. Borzyszkowski, Wielewskie góry. Dzieje Wiela i jego kalwarii, Gdańsk 1986; E. Filipski, Sanktuarium kalwaryjskie w Wielu, Pelplin 2000; M. Jania-Szczechowiak, F. Mudzo, Inwestor $i$ wykonawca. Owocne, ale trudne współdziałanie księdza z architektem. Proboszcz Parafii Wiele Józef Szydzik i monachijski architekt Theodor Mayr, w: Kalwaria Wielewska. Stulecie trwania (1915-2015), red. B. Górczyńska-Przybyłowicz, F. Mudzo, M. Jania-Szczechowiak, Instytut Historii UAM: Poznań 2017, s. 127-144; J. Perszon, Kalwaria Wielewska jako nowe centrum kultu pasyjnego na Kaszubach, w: Kalwaria Wielewska. Stulecie trwania (1915-2015), red. B. Górczyńska-Przybyłowicz, F. Mudzo, M. Jania-Szczechowiak, Instytut Historii UAM: Poznań 2017, s. 24-42.

76 Zob. J. Perszon, Skarb w naczyniu glinianym. Ksiadz Zygmunt Trella-proboszcz i pielgrzym z Mechowa, Gdańsk 2013.

77 Oczywiście taki wniosek można sformułować post factum, oceniając owoce duchowe (religijne) konkretnego przedsięwzięcia. O znaczeniu „nadprzyrodzonego zmysłu wiary” zob. Sensus fidei w życiu Kościoła. Dokument Międzynarodowej Komisji Teologicznej, Kraków 2015.

78 Bractwo Świętego Krzyża, współorganizujące od ponad 300 lat pąć na Kalwarię Wejherowską, powstało w tym samym czasie, co parafia w Kościerzynie. Zob. L. Jażdżewski, Pielgrzymki kościerskie na Kalwarię Wejherowska, Wejherowo 2008, s. 136-137. W Piasecznie Bractwo Szkaplerza Świętego założono w 1640 r. (J. Wiśniewski, Parafia i sanktuarium maryjne w Piasecznie w okresie nowożytnym (XVI-XVIII w.), Gniew 2008, s. 141-142.). Zob. J. Perszon, Piaseczno. Sanktuarium i ruch pątniczy w czasach wspótczesnych (XX i XXI wiek), s. 74. Bractwo Matki Boskiej Bolesnej przy kościele parafialnym w Gniewie oficjalnie zaistniało w 1801 r., jednak kontynuowało tradycję sprzed wielu lat. Zob. A. Korecki, Sanktuarium Maryjne w Łąkach Bratjańskich, Bernardinum: Pelplin 2002, s. 68-70. O zaangażowaniu działaczy ZKP w rozwój sanktuarium Królowej Kaszub w Sianowie zob. E. Pryczkowski, Swiónowsko nasza Matinko. Dzieje parafii i sanktuarium oraz cuda Królowej Kaszub, s. 295-196. 
tzw. Prusy Królewskie to diecezja chełmińska) od tego sanktuarium ${ }^{79}$. Ostre prześladowanie Kościoła kontynuowały - poczynając od rozbiorów Polski - władze Prus. Antykościelne nastawienie Prus do Kościoła uderzyło bezpośrednio w Polaków. Już w 1764 roku rząd pruski zakazał na Śląsku pielgrzymek ,za granicę”, a zwłaszcza na Jasną Górę. Dość często - w imię germanizacji i protestantyzacji państwa - przejmowano kościoły katolickie i przekazywano ewangelikom. Biskupom - którzy musieli składać przysięgę na wierność królowi Prus - zakazano bez zgody władz zwoływania synodów i odbywania wizytacji. Dokonano zmian administracyjnych w strukturze Kościoła katolickiego, zaś kurie zobowiązano do używania języka niemieckiego ${ }^{80}$. Władze Prus konsekwentnie zmierzały do likwidacji stolicy prymasowskiej ${ }^{81}$. Pierwsze kasaty klasztorów - związane z kontrybucją wojenną na rzecz Francji (lata 1806-1807) - dokonano na Śląsku i ziemiach zabranych Polsce. W latach 1810-1811 zlikwidowano praktycznie wszystkie domy zakonne na Śląsku, m.in. na Górze św. Anny ${ }^{82}$. Kolejne kasaty (w latach 18151841) objęły zakony na Pomorzu, Warmii i w Wielkim Księstwie Poznańskim, m.in. klasztor reformatów w Pakości, związany z miejscową Kalwariąa ${ }^{83}$. Położenie Kościoła na terenach polskich zaboru pruskiego stało się jeszcze trudniejsze po 1831 roku. W 1833 roku król pruski przyjął projekt kasaty wszystkich pozostałych placówek zakonnych. Celem tych działań było całkowite podporządkowanie Kościoła państwu, z drugiej zaś strony pełna germanizacja ludności polskiej. W 1837 roku doszło do konfliktu między rządem a arcybiskupem gnieźnieńskim Marcinem Duninem, który protestował przeciw antykościelnym represjom ${ }^{84}$.

79 Zob. S. Z. Jabłoński, Jasna Góra. Ośrodek kultu maryjnego (1864-1914), Lublin 1984.

80 Zob. B. Kumor, Historia Kościoła. Czasy nowożytne. Kościół w okresie absolutyzmu i oświecenia, cz. 6, Lublin 1985 s. 243-244.

81 Zob. tenże, Ustrój i organizacja Kościoła polskiego w okresie niewoli narodowej (1772-1918), Kraków 1980 s. 97-145.

82 Sanktuarium na Górze św. Anny nazywano „twierdzą polskości”. W 1810 rząd skasował klasztor franciszkanów, ale nabożeństwa kalwaryjskie kontynuowali kapłani diecezjalni. W 1832 r. klasztor i kalwaria zostały przekazane w zarząd biskupowi wrocławskiemu; w $1858 \mathrm{r}$. kuria wrocławska zakupiła kościół i klasztor, przekazując obiekty franciszkanom. Rok później przybyli tam franciszkanie z prowincji saksońskiej. Na stulecie kalwarii (od uroczystości Wniebowzięcia NMP do Podwyższenia Krzyża św.) przybyło ok. 400 tys. pątników ze Śląska, Czech, Moraw, Słowacji, Królestwa Polskiego, Galicji i Wielkopolski. Zob. J. Górecki, Pielgrzymowanie Górnośląaków na Górę sw. Anny w latach 1859-1914. Studium teologicznopastoralne, Katowice 2002, s. 39-40.

83 Zob. F. Mróz, Geneza i typologia sanktuariów Pańskich w Polsce, Kraków 2005, pr. dr., mps Archiwum Zakładu geografii UJ, s. 159-160.

${ }^{84}$ Prymas protestował przeciw zarządzeniu o małżeństwach mieszanych, domagając się respektowania kościelnych regulacji o deklaracji wychowania potomstwa w wierze katolickiej. Sprzeciwiał się likwidacji bractw i stowarzyszeń kościelnych oraz zamykaniu przez władze świątyń katolickich (m.in. kościoła Bożego Ciała w Poznaniu). Zob. Z. Zieliński, Kościół katolicki w Wielkim Księstwie Poznańskim w latach 1848-1965, Lublin 1973 s. 61-62. 
W maju 1839 roku prymas Polski został uwięziony w Kołobrzegu, skąd - uwolniony w 1840 r. tryumfalnie wrócił do Poznania ${ }^{85}$. Kolejna fala prześladowań Kościoła katolickiego związana była z tzw. Maigesetze, czyli „ustawami majowymi”. Ich następstwem było zniesienie w całych Prusach (ustawa z 31 maja 1875) wszystkich klasztorów z wyjątkiem tych, które prowadziły dzieła charytatywne (szpitale, domy dla chorych psychicznie itd.) ${ }^{86}$.

Trudności w przekraczaniu granicy Prus sprawiły, że na przełomie XIX/XX wieku ruch pielgrzymkowy na Pomorzu koncentrował się na sanktuariach lokalnych; kierunkiem uczęszczanym od lat 80 . tego stulecia stało się dla wielu mieszkańców Kaszub miejsce objawień maryjnych w Gietrzwałdzie ${ }^{87}$. Babcia autora, Paulina, mieszkając na pocz. XX wieku w parafii Rozłazino, należała do tamtejszej Sodalicji Mariańskiej. Nie tylko wspominała pielgrzymkę koleją do Gietrzwałdu, ale do końca życia miała nad łóżkiem barwny oleodruk, upamiętniający zjawienie się Maryi warmińskim dziewczętom. Paradoksalnie, gdy w PRL w latach 60. i 70. XX wieku zakazano (poza warszawską i kaliską) tradycyjnych, długodystansowych pielgrzymek na Jasną Górę, ,ruszyła” wśród młodych Polaków moda na piesze wędrowanie. Gdy Pielgrzymka Warszawska wskutek tego w końcu lat 70. urosła do kilkudziesięciu tysięcy uczestników, władze niejako „musiały” - dla uniknięcia katastrofy humanitarnej - zezwolić na nowe, np. w 1979 Pieszą Pielgrzymkę Pomorską z Torunia na Jasną Górę ${ }^{88}$. Zrazu uczestniczyło w niej „tylko” ok.

${ }^{85}$ W maju 1841 roku prymas Dunin poprowadził dziękczynną procesję na kalwarię w Pakości, z udziałem ok. 30 tys. pielgrzymów. Zob. F. Mróz, Geneza i typologia, s. 160.

${ }^{86}$ Najpierw 11 marca 1872 r. „ustawa o nadzorze szkolnym” pozbawiła Kościół wpływu na szkołę. Z kolei 4 lipca 1872 r. ustawa antyzakonna wykluczyła z Rzeszy jezuitów, redemptorystów i sercanki. W maju 1873 r. minister kultu A. Falk przeprowadził w Landtagu 4 ustawy „majowe” dotyczące kształcenia i zatrudniania duchowieństwa, jurysdykcji papieskiej na terenie Rzeszy, środków dyscyplinarnych Kościoła i wystąpienia z Kościoła. W 1874 r. wydano ustawę o zarządzie majątków kościelnych (rząd zajmował majątek placówek „nieprawnie” obsadzonych), ustawę banicyjną, która pozwalała wydalać z Rzeszy duchownych wykraczających przeciw prawom majowym. W $1875 \mathrm{r}$. wprowadzono urzędy stanu cywilnego i obowiązkowe małżeństwa cywilne oraz zlikwidowano wszystkie zakony z wyjątkiem opiekujących się chorymi. Pius IX uznał ustawy za niebyłe i obłożył stosujących je księży (bardzo nielicznych) ekskomuniką. Księża święceni niezgodnie z prawem nie byli dopuszczani do pracy. Ok. 1000 parafii pozbawiono duszpasterzy, 9 biskupstw było nieobsadzonych, abp Mieczysław Ledóchowski został skazany na 5 lat więzienia za niestosowanie praw majowych. Dopiero w 1882 r. zaczęto antykościelne restrykcje łagodzić, a odwołano je w 1887 r. Zob. Z. Zieliński, Kulturkampf, EK 10, kol. 205-207.

87 Por. T. Grygier, Uroczystości gietrzwatdzkie, ich aspekt katolicki oraz polski w latach 1877-1944 w świetle akt wschodnio-pruskich, „Studia Warmińskie” 14(1977) s. 226-323.

88 Zob. A. Kamiński, Piesza Pomorska Pielgrzymka na Jasną Górę w latach 1979-1991, Pelplin 2013, s. 55-56. Autor zaznacza, że inicjatorami Pieszej Pielgrzymki Pomorskiej byli księża: Stanisław Kardasz z Torunia i Tadeusz Balicki z Gdańska. W jej organizację zaangażowali się świeccy: Anna i Jan Łopuszańscy, Tadeusz Mikołajczyk - związani z duszpasterstwem akademickim w Gdańsku, oraz Barbara Filipiak i lekarz med. Paweł Wudarski. Wszyscy wcześniej 
500 osób. W kolejnych latach rozrosła się ona do kilkunastu tysięcy pątników, gromadząc grupy z diecezji chełmińskiej, gdańskiej, koszalińsko-kołobrzeskiej i warmińskiej ${ }^{89}$.

Jak już wspomniano, „znakiem czasu” schyłkowych dziesięcioleci XX wieku był potężny impuls pielgrzymkowy skierowany na Jasną Górę. W 1982 roku wyruszyła - z hasłem „600 km na sześćsetlecie” - ze Swarzewa I Piesza Pielgrzymka Kaszubska, skupiająca uczestników z całych Kaszub. O ile w jubileuszowej wędrówce wzięło udział ok. 600 osób, o tyle w kilku kolejnych latach ich liczba prawie się podwoiła ${ }^{90}$. W 1984 roku na szlak jasnogórski wyszła I Pielgrzymka Gdańska, a w kolejnym (1986) Pielgrzymka Gdyńska. Ta pierwsza prowadziła co roku do Częstochowy - aż do połowy lat 90. XX wieku - kilka, a w szczytowym momencie nawet kilkanaście tysięcy pątników ${ }^{91}$. W 1991 roku wyruszyła na szlak jasnogórski Pielgrzymka Kościerska (od 2015 r. Pielgrzymka Kaszubska Diecezji Pelplińskiej), która wystartowała z Kościerzyny 30 lipca, by połączyć się z Pielgrzymką Pomorską w Kiedrzynie. Przez wiele lat wędrowało w niej pomiędzy 300 a 400 osób, zwłaszcza z powiatów kartuskiego, kościerskiego, lęborskiego i wejherowskiego $0^{92}$.

Jednak już pod koniec lat 80 . XX wieku widać stopniowy spadek liczby jasnogórskich pielgrzymów. W drugiej dekadzie obecnego stulecia jest on wręcz gwałtowny, co może wynikać z galopującej (a spowodowanej inwazją rzeczywistości wirtualnej) dechrystianizacji młodego pokolenia.

uczestniczyli w Pielgrzymce Warszawskiej. Od strony eklezjalnej „,promotorem” i organizatorem pąci był ordynariusz chełmiński bp Bernard Czapliński.

89 Zob. A. Kamiński, Piesza Pomorska Pielgrzymka na Jasna Górę w latach 1979-1991, s. 114-115.

90 Oficjalna statystyka Archiwum Diecezji Pelplińskiej podaje następujące liczby: 1983-850 osób; 1984-900 osób; 1985-800 osób. Zob. A. Kamiński, Piesza Pomorska Pielgrzymka na Jasna Górę w latach 1979-1991, s. 114-115. Wydaje się jednak, że są to dane zaniżone i niedokładne. Ks. Trella, jako kierownik Pielgrzymki Kaszubskiej, zobowiązany był do odprowadzania do centrali Pielgrzymki Pomorskiej ,,składki” od każdego zgłoszonego pątnika. Dlatego (informacje K.S. z Pucka) podawane liczby nie uwzględniały tych, którzy szli tylko część trasy.

91 W ramach Pielgrzymki Pomorskiej w grupach gdańskich odnotowano udział: w 1981-600 osób; 1982-1809 osób; 1983-2892 osoby (w pięciu grupach). Zob. A. Kamiński, Piesza Pomorska Pielgrzymka na Jasną Górę w latach 1979-1991, s. 114-115.

92 Inform.: ks. A. Bączkowski z Kościerzyny; ks. J. Lipski ze Starogardu Gd.; ks. J. Ostrowski z Lipusza; ks. M. Trybowski z Kartuz. Zob. też A. Kamiński, Piesza Pomorska Pielgrzymka na Jasna Górę w latach 1979-1991, s. 107; A. Szopiński, Piesza Pielgrzymka na Jasna Górę, w: Kościót Pelpliński na swoje XV-lecie 1992-2007, red. W. Klawikowski, Pelplin 2008, s. 280-281. 


\section{TRANSFORMACJA KASZUBSKIEGO (POMORSKIEGO) PATTICTWA POD KONIEC XX WIEKU}

Wskazane wyżej czynniki aktywnie wpływające na rozwój (i zanik) konkretnych sanktuariów oraz związanego z nimi ruchu pątniczego pokazują, że w przypadku Kaszub trudno mówić o jakimś status quo. Labilna jest nie tylko religijno-społeczna „,pozycja” sanktuariów, ale przede wszystkim ruch pątniczy w jego szerokim kontekście. Brak niestety dokładnych badań, które pozwalałyby zdiagnozować kaszubskie pątnictwo nie tylko w aspekcie ilościowym, demograficznym (wiekowym) czy terytorialnym. Bardzo istotną rzeczą jest bowiem ,jakość” uczestnictwa w pielgrzymce (odpuście), rozumiana zarówno jako udział (zaangażowanie) w konkretnych obrzędach (rytuałach): spowiedzi, mszy św., komunii, różańcu, obchodach stacji kalwaryjskich, ale także wewnętrzne (duchowe) nastawienie, motywacje, przeżycia i szeroko pojęte doświadczenie religijne, aktualizowane w sanktuarium i w drodze do niego i z niego.

Kilkuwiekowa tradycja kaszubskiego pątnictwa (przede wszystkim na Kalwarię Wejherowską) mogłaby sugerować, że ruch peregrynacyjny stanowi pewną, $\mathrm{w}$ swej zasadniczej formie i treści, niezmienną kontynuację. Jest $\mathrm{w}$ tym sporo racji. Jednakowoż tradycja ta wielorako uwikłana jest w historię żywych ludzi: osób, rodzin, parafii, regionu, tudzież małej i wielkiej polityki. W wieku XX wędrujący do swoich sanktuariów Kaszubi ,przechodzili” przez przynajmniej kilka systemów politycznych i państwowych: czasy cesarskich Niemiec, niecałe dwadzieścia lat II Rzeczypospolitej, straszliwe lata II wojny światowej, 45 lat komunizmu w Polsce Ludowej, wreszcie jedenaście lat wolnej Ojczyzny. Bez wątpienia sama obecność i trwanie na swych terytoriach autochtonicznej ludności kaszubskiej aktywnie korelowała z katolickimi miejscami świętymi. Sanktuaria te „żyły” dla Kaszubów, ale także dzięki ich pobożności. Przez większą część minionego stulecia Wejherowo, Swarzewo, Sianowo i Wiele były dla nich przestrzenią doświadczania wspólnoty, umacniały ich duchową (religijną) tożsamość, utrzymywały więź z Bogiem i Jego Matką, pozwalały przetrwać prześladowania i presję nieprzyjaciół. Walnie przyczyniły się do ugruntowania polskiego patriotyzmu Kaszubów, jednocześnie afirmując ich język i kulturową specyfikę.

Zmiany, jakie zachodziły w pielgrzymowaniu i pobycie w sanktuariach, były niemal niedostrzegalne. Przez wieki podróżowano pieszo lub zaprzęgami konnymi; modlono się i śpiewano własnymi siłami, korzystając z wyćwiczonej powtarzaniem pamięci oraz - zwłaszcza w wieku XIX - z coraz liczniejszych modlitewników/ śpiewników tzw. kalwaryjek. Przyspieszyły one wskutek transformacji technologicznej. W latach 60. XX wieku w sanktuariach i w drodze zaczęto korzystać z elektronicznego nagłośnienia, które (często nielegalnie) sprowadzano z Zachodu. Spowodowało to znaczący wzrost roli kapłana-przewodnika. Dzięki wzmacnia- 
czom duchowny zdolny był do przewodzenia śpiewom i modlitwom, a głoszone nauki (konferencje duchowne) łatwiej docierały do pątników. Aktywny i uzdolniony ksiądz nie musiał już trzymać się tradycji i robić w drodze tego, „co zawsze robiono", ale mógł przeforsować własną wizję pielgrzymowania i przeżywania pobytu w miejscu świętym ${ }^{93}$.

Prawdziwą rewolucję w peregrynacji przyniosła na Kaszuby Pielgrzymka Warszawska, w której - jak wspomnieliśmy - w latach 70. XX wieku uczestniczyły co roku setki Kaszubów: świeckich, duchownych i osób zakonnych. Ta organizowana przez paulinów pielgrzymka wypracowała model wędrowania, który znakomicie trafiał w zapotrzebowanie pątników, a jednocześnie pozwalał realizować ideał pątnictwa, czyli rekolekcje w drodze. Ta nowa tradycja weszła w kaszubskie pątnictwo za sprawą młodych wikariuszy, którzy atrakcyjne wzorce Pielgrzymki Warszawskiej zaszczepiali np. na prastarej Pielgrzymce Kościerskiej ${ }^{94}$. Jej elementem jest faktyczne przewodzenie kompanii przez księdza; dominacja śpiewów nowych piosenek (pielgrzymkowych i ewangelicznych, których „wysyp” miał miejsce w latach 70. i 80. XX wieku) przy akompaniamencie gitar; zwracanie się do siebie per „siostra” i „brat”; przewożenie cięższych feretronów na wózku (np. Pielgrzymka Kościerska); transport bagaży i słabszych pątników ciągnikami rolniczymi i autami ciężarowymi; zakaz palenia tytoniu i picia alkoholu; wygłaszanie przez kapłana w czasie marszu konferencji ascetycznej; możliwość skorzystania z sakramentu pokuty w drodze ${ }^{95}$. Wraz z upowszechnieniem się nowej tradycji zmienił się znacząco skład wiekowy pielgrzymów. Od początku lat 80. (co trwa faktycznie do dziś) dominującą grupą wiekową stała się młodzież (zwłaszcza szkół ponadpodstawowych). Tym samym zaniknął tradycyjny śpiew „,własnym głosem”; poniechano wykonywania starych pieśni pasyjnych, maryjnych i przygodnych (oraz używania porządnych kancjonałów); ograniczono znaczenie towarzyszącej pątnikom kapeli; większość pątników po dotarciu do sanktuarium (z wyjątkiem

93 Każda kompania pielgrzymkowa miała, wyłonionych samorzutnie, własnych liderów i organizatorów. Były to osoby świeckie (prawie zawsze obdarzeni autorytetem mężczyźni), którzy tradycyjnie prowadzili modlitwy i śpiewy w drodze, regulowali tempo marszu, decydowali o długości postojów, troszczyli się o należyty szyk podróżowania, reagowali na potencjalne nadużycia i wykroczenia, pilnowali przestrzegania dawnych zwyczajów. Wzmocnienie" roli księdza oznaczało więc odebranie tym osobom znacznych kompetencji, co nieraz prowadziło do zadrażnień i konfliktów.

94 Pionierem unowocześnienia tej pielgrzymki był - od 1979 r. - ks. Bogdan Lipski. Jego innowacje spotkały się wtedy z oporami części starszych pątników. Zob. L. Jażdżewski, Pielgrzymki kościerskie na Kalwarię Wejherowska, s. 146-147.

95 Znakomitą (nie tylko literacko) analizą zmian w tradycji Pielgrzymki Kościerskiej jest książka Edmunda Szczesiaka (Droga do nieba. Śladami Remusa. Mała odyseja kaszubska, Gdynia-Wejherowo 2017), oparta o osobiste pielgrzymowanie autora (w 2016 r.) oraz rozległą kwerendę (wywiady, archiwa) przez niego przeprowadzoną. 
Pielgrzymki Kościerskiej) wraca na noc (autokarami, samochodami osobowymi) do rodzinnego domu ${ }^{96}$.

Bez wątpienia nowa tradycja, choć wiąże się z częściowym zarzuceniem dawnej formy pątnictwa, jest duchowo owocna i społecznie nośna. By w pełni ją ocenić, potrzeba dokładnych badań jakościowych, które odpowiedziałyby na pytanie, jak młodzi Kaszubi i Pomorzanie przeżywają zarówno udział w pielgrzymkach (zwłaszcza dłuższych, kilkudniowych), jak i sam pobyt w miejscu świętym (sanktuarium). Istotnym zagadnieniem jest także motyw pielgrzymowania oraz związek pątnictwa z życiem codziennym.

\section{PODSUMOWANIE}

Kulturowo-cywilizacyjne przemiany mają więc istotne (a częstokroć decydujące) znaczenie w funkcjonowaniu sanktuariów i związanego z nimi ruchu pątniczego. $Z$ punktu widzenia całej historii zbawienia jest to konstatacja banalna i oczywista. Jeśli kultura to przede wszystkim sposób organizacji życia danej zbiorowości (ludu, społeczeństwa, grupy etnicznej) ${ }^{97}$, to zmiany w jednym wymiarze tej organizacji automatycznie naruszają status quo całości. Życie religijne, a tym bardziej ruch pątniczy, nie jest więc samą wypadkową wiary, praktyk religijnych czy wiedzy teologicznej, ani nawet samej tradycji - przekazu wzorców zachowań z pokolenia na pokolenie - ale wprost zależy od całego systemu kulturowego. Ten zaś składa się z wielu czynników: politycznych, gospodarczych (sposób gospodarowania, źródła utrzymania, środki komunikacji), wewnątrzkościelnych (gorliwość duszpasterzy, pobożność w rodzinach, sprawność organizacyjna duchowieństwa i aktywnych świeckich, pogłębione motywacje pątników), mody kulturowej - mało uchwytnych, ale silnie oddziałujących trendów, które ułatwiają (lub do niej zniechęcają) decyzję udziału w pielgrzymce czy w odpuście. Jeśli serio bierze się - wywiedzione z Objawienia - nauczanie Kościoła o zależności/synergii wolnej woli człowieka i Bożej łaski, w rozpoznaniu i ocenie ruchu pątniczego trzeba uwzględnić rzeczywisty wymiar nadprzyrodzony. Ten zaś z oczywistych względów wymyka się spod kontroli i przewidywań. Potoczna obserwacja i badania socjologiczne nie są w stanie np. adekwatnie wyjaśnić pielgrzymkowego zrywu polskiej (i kaszubskiej) młodzieży w ostatnim ćwierćwieczu XX stulecia. Nie da się też racjonalnie uzasadnić rosnącego znaczenia sanktuarium Królowej Kaszub w Sianowie w czasie, gdy dwa pozostałe (historycznie mocno ugruntowane) sanktuaria w Wejherowie (Kalwaria) i Swarzewie wykazują w ostat-

${ }^{6}$ Inform.: ks. S. Majkowski ze Swarzewa; ks. E. Grzedzicki z Sianowa; o. M. Janus; o. D. Szustak z Wejherowa; ks. J. Flisikowski z Wiela; ks. J. Ostrowski z Lipusza; ks. A. Bączkowski z Kościerzyny.

97 Zob. B. Wildstein, Międzymorze, s. 247. 
nich kilkunastu latach stagnację. Trzeba tedy zachować daleko idącą powściągliwość w prognozowaniu przyszłości ruchu pielgrzymkowego na Kaszubach. $\mathrm{W}$ minionych wiekach przynajmniej kilka razy (reformacja, kulturkampf, czasy komunizmu) wszystko wskazywało na nieuchronny zmierzch tradycji pątniczej. Stało się jednak inaczej. Rzeczywistość wiary każe - zwłaszcza w dłuższej perspektywie czasowej - brać pod uwagę realne działanie Boga, który pozostaje Panem historii. Stąd i nasza historia jest zawsze historią zbawienia.

\section{Bibliografia}

Adamczyk J., Szczególna przyczyna pobożności jako istotny warunek istnienia sanktuarium (kan. 1230). Aspekt kanoniczny, „Salvatoris Mater” 13(2011) nr 1-2, s. 230-246.

Bania Z., Kobielus S., Jasna Góra, Warszawa 1983.

Bartnik Cz. S., Chrześcijańska nauka o narodzie wedtug prymasa Stefana Wyszyńskiego, Lublin 1982.

Beyga P., Pobożność ludowa jako miejsce urzeczywistniania się sensus fidei na przykladzie dogmatu o wniebowzięciu Maryi Dziewicy, „Teologia w Polsce” 10,2 (2016), s. 165-175.

Borzyszkowski J., Pelplin jako ośrodek życia kulturalnego na Pomorzu w XIX i XX wieku, w: tenże, $Z$ dziejów kościoła katolickiego na Kaszubach i Pomorzu w XIX i XX wieku, Gdańsk-Pelplin 2000, s. 130-161.

Borzyszkowski J., Sanktuaria maryjne Pomorza $w$ diecezji chetmińskiejlegenda, tradycja i historia, w: tenże, Z dziejów kościoła katolickiego na Kaszubach i Pomorzu w XIX i XX wieku, Gdańsk-Pelplin 2000, s. 236-269.

Borzyszkowski J., Wielewskie Góry. Dzieje Wiela i jego kalwarii, Gdańsk 1986.

Chelini A., Branthomme H., Drogi Boże. Historia pielgrzymek chrześsijańskich, Warszawa 1996.

Czachowski H., Cuda, wizjonerzy i pielgrzymi. Studium religijności mirakularnej końca XX wieku w Polsce, Warszawa 2003.

Danielewicz Z., Traktat o rzeczywistości ostatecznej, w: w: M. Kowalczyk, Z. Danielewicz, Dogmatyka tom 6. Traktat o stworzeniu. Traktat o rzeczywistości ostatecznej, Warszawa 2007 s. 287-550.

Delsol Ch., Nienawiść do świata. Totalitaryzmy i ponowoczesność, Warszawa 2017.

Fankidejski J., Obrazy cudowne i miejsca $w$ dzisiejszej diecezji chetmińskiej podtug urzędowych akt kościelnych i miejscowych podań, Gdynia 2011.

Filipski E., Sanktuarium kalwaryjskie w Wielu, Pelplin 2000.

Górecki J., Pielgrzymki na Górnym Ślasku w latach 1869-1914, Katowice 1994. 
Górecki J., Pielgrzymowanie Górnośląaków na Górę sw. Anny w latach 1859-1914. Studium teologicznopastoralne, Katowice 2002.

Grygier T., Uroczystości gietrzwatdzkie, ich aspekt katolicki oraz polski w latach 1877-1944 w świetle akt wschodnio-pruskich, „Studia Warmińskie” 14(1977) s. 226-323.

Grzegorz z Sambora, Czestochowa poemat wydany w roku 1568 u Siebeneychera z łacińskiego na język polski, tłum. W. Stroka, Kraków 1896.

Gucewicz D., Władze PRL wobec sanktuarium w Piasecznie, w: Kultura materialna i duchowa sanktuarium w Piasecznie, red. W. Pikor, Pelplin 2018, s. 117-147.

Iwan R., Prawa, obowiązki i zagrożenia narodu wedtug prymasa Stefana Wyszyńskiego, Lublin 1989.

Jabłoński S. Z., Jasna Góra ośrodek kultu maryjnego (1864-1914), Lublin 1984.

Jania-Szczechowiak M., Mudzo F., Inwestor $i$ wykonawca. Owocne, ale trudne współdziałanie księdza z architektem. Proboszcz Parafii Wiele Józef Szydzik i monachijski architekt Theodor Mayr, w: Kalwaria Wielewska. Stulecie trwania (1915-2015), red. B. Górczyńska-Przybyłowicz, F. Mudzo, M. Jania-Szczechowiak, Poznań 2017, s. 127-144.

Jażdżewski L., Pielgrzymki kościerskie na Kalwarię Wejherowska, Wejherowo 2008.

Kamiński A., Piesza Pomorska Pielgrzymka na Jasna Górę w latach 19791991, Pelplin 2013.

Koch K., Świecie, Encyklopedia Katolicka, t. 19, Lublin 2013, kol. 363-364.

Kongregacja ds. Kultu Bożego i Dyscypliny Sakramentów, Dyrektorium o pobożności ludowej i liturgii. Zasady i wskazania, Poznań 2003.

Korecki A., Sanktuarium Maryjne w Łakach Bratjańskich, Pelplin 2002.

Kujot S., Miejsca cudowne Najświętszej Maryi Panny w Prusach Królewskich (Dyecezya Chetmińska), w: Księga Pamiątkowa Maryańska ku czci pięćdziesięciolecia ogłoszenia dogmatu o Niepokalanym Poczęciu Najświętszej Mary Panny, Lwów 1905.

Kumala J., Fenomen zjawień maryjnych w przestrzeni pobożności ludowej, w: Wokót objawień maryjnych. Polskie pokłosie XXII Międzynarodowego Kongresu Mariologiczno-Maryjnego w Lourdes (4-8 IX 2008), red. T. Siudy, G. M. Bartosik, Częstochowa 2009, s. 106-120.

Kumor B., Historia Kościoła. Czasy nowożytne. Kościół w okresie absolutyzmu i oświecenia, cz. 6, Lublin 1985.

Kumor B., Ustrój i organizacja Kościoła polskiego w okresie niewoli narodowej (1772-1918), Kraków 1980.

Kustusz G. A., O. Ambroży Lewalski-duszpasterz i patriota, w: Wejherowo. Dzieje, kultura, środowisko. Materiaty z konferencji naukowej Wejherowo 28-29.05.1993 r., Wejherowo 1993, s. 179-188. 
Kustusz G. A., Święte Góry Wejherowskie, Gdynia 1991.

Lewandowski J., Naród w nauczaniu kardynała Stefana Wyszyńskiego, Warszawa 1982.

Łysiak W., Święta przestrzeń. O pielgrzymkach, pielgrzymowaniu, miejscach pielgrzymkowych i pobożności ludowej w dawnym Księstwie Pomorskim, Poznań 2010.

Mańkowski A., Pod rządami pruskimi (1815-1846, 1846-1871, 1871-1918), „Roczniki Historyczne” 3:1927, s. 255-323.

Międzynarodowa Komisja Teologiczna, Sensus fidei w życiu Kościoła, tłum. M. Moskal, Kraków 2015.

Mross H., Bukolt Augustyn, w: tenże, Słownik biograficzny kapłanów diecezji chetmińskiej wyświęconych w latach 1821-1920, Pelplin 1995, s. 27.

Mróz F., Geneza i typologia sanktuariów Pańskich w Polsce, Kraków 2005.

Perszon J., Kalwaria Wielewska jako nowe centrum kultu pasyjnego na Kaszubach, w: Kalwaria Wielewska. Stulecie trwania (1915-2015), red. B. Górczyńska-Przybyłowicz, F. Mudzo, M. Jania-Szczechowiak, Poznań 2017, s. 24-42.

Perszon J., Pobożność pielgrzymkowa Kaszubów. Tradycja i współczesność, w: Pelpliński Areopag. Religijność Pomorza, red. Ł. Grzędzicki, J. Szulist, Gdańsk 2016, s. 37-68.

Perszon J., Skarb w naczyniu glinianym. Ksiądz Zygmunt Trella - proboszcz i pielgrzym z Mechowa, Gdańsk 2013.

Perszon J., Trudności eklezjalnej recepcji objawień prywatnych, ,Studia Koszalińsko-Kołobrzeskie", 26(2019), s. 133-164.

Perszon J., Vir Fidelis. Ksiądz Mieczysław Sumiński. Proboszcz w Luzinie i dziekan wejherowski, Pelplin 2017.

Piszcz E., Łąki Bratjańskie - najstarsze miejsce kultu maryjnego $w$ diecezji chełmińskiej, „Nasza Przeszłość”, t. XXXIV,1971, s 177-203.

Polak W., Materiały Stużby Bezpieczeństwa związane z inwigilacją uroczystości odpustowych w Sanktuarium Maryjnym w Piasecznie, w: Diecezja chetmińska w czasach komunizmu (1945-1990), red. W. Polak, W. Rozynkowski, J. Sziling, Pelplin 2009, s. 305-356.

Potykanowicz-Suda L., Państwo a Kościół katolicki w województwie gdańskim w latach 1945-1970, Warszawa 2011.

Pryczkowski E., Królowa Morza. Dzieje kaszubskiego sanktuarium Matki Boskiej Swarzewskiej, Swarzewo-Banino 2019.

Pryczkowski E., Swiónowsko nasza Matinko. Dzieje parafii i sanktuarium oraz cuda Królowej Kaszub, Banino 2016.

Puzdrowski E., Najświętsza Maryja Panna z Pomorza w poezji i pieśni, „Studia Pelplińskie" t. XVII (1986), s. 57-69.

Pyc M., Pobożność ludowa a sensus fidei, „Studia Gnesnensia” t. XXVII (2013), s. całość 47-57. 
Rafalska D., Medjugorie: prawda czy fatsz ? Identyfikacja domniemanych „objawień" z Medjugorie w świetle kryteriów teologiczno-psychologicznych, Lublin 2003.

Rogalski A., Kościót katolicki na Ślasku, Warszawa 1955.

Rogalski A., Kościót katolicki na Warmii i Mazurach, Warszawa 1956.

Roszak P., Tykarski S., Popular Piety and Devotion to Parish Patrons in Poland and Spain, 1948-1998, „Religions” 2020,11,658.

Ryszka Cz., Idzie wierna Warszawa. 300 lat Warszawskiej Pielgrzymki Pieszej, Częstochowa-Warszawa 2010.

Seweryn D., Nasze korzenie. Wspomnienia i świadectwo, Kraków 2019.

Sikora A. R., Droga do koronacji Obrazu Matki Bożej Wejherowskiej w zapisach Kroniki Wejherowskiego Klasztoru z lat 1946-1999, w: Kult Pani Ziemi Wejherowskiej w Duchowej Stolicy Kaszub. Materiaty z sesji naukowej z okazji X-lecia koronacji obrazu Matki Bożej Wejherowskiej, Wejherowo, 4 czerwca 2009, red. A.R. Sikora, Wejherowo 2010, s. 41-55.

Siwecki L., 'Sensus fidei' jako dar Ducha Świętego dla Kościoła, „Studia Theologica Varsoviensia" 43/1, 2005, s. 79-98.

Sołjan I., Kalwaria Zebrzydowska na tle innych ośrodków w Karpatach Polskich, „Peregrinus Cracoviensis” z. 2, 1995, s. 77-90.

Sumption J., Pilgrimage. An Image of Mediaeval Religion, Totowa, NJ 1976.

Szczerba D., Sekret Medjugorie. Objawienia, historia, świadectwa, Kraków 2017.

Szczesiak E., Droga do nieba. Śladami Remusa. Mała odyseja kaszubska, Gdynia-Wejherowo 2017.

Sziling J., Polityka okupanta hitlerowskiego wobec Kościoła katolickiego 1939-1945, Poznań 1970.

Szopiński A., Piesza Pielgrzymka na Jasna Górę, w: Kościół Pelpliński na swoje XV-lecie 1992-2007, red. W. Klawikowski, Pelplin 2008, s. 279-288.

Terlikowski T. P., Franciszek Blachnicki. Ksiądz, który zmienił Polskę, Kraków 2021.

Trzeciakowski L., Kulturkampf w zaborze pruskim, Poznań 1970.

Walkusz J., Kalwaria Wejherowska pod zarządem duchowieństwa diecezjalnego, w: Kult Matki Bożej na Kaszubach i Pomorzu. Studia nad kultura religijna Kaszubów i Pomorzan. Materiały z sympozjum mariologicznego $w$ Wejherowie 17-18 maja 1999 r., red. G.A. Kustusz, B.J. Soiński, Wejherowo 1999, s. 136-146.

Walkusz J., Kalwaria Wejherowska pod zarządem duchowieństwa diecezjalnego, w: tenże, Kościót na drogach pomorskiej przeszłości. Studia i szkice z XIX i XX wieku, Lublin 2014, s. s. 47-80.

Walkusz J., W cieniu połamanego krzyża. Studia i szkice z dziejów Kościoła katolickiego na Pomorzu Nadwiślańskim w latach 1939-1945, Tczew-Pelplin 1999. 
Więckowiak J., Kalwarie barokowe w Polsce, Gdańsk-Wejherowo 2006.

Wildstein B., Bunt i afirmacja. Esej o naszych czasach, Warszawa 2020.

Wildstein B., Odpowiedzialność Marksa, w: tenże, O kulturze i rewolucji, Warszawa 2018, s. 129-180.

Witkowska A., The Cult of the Virgin Mary in Polish Religiousness from the 15th Century, w: The Common Christian Roots of the European Nations. An International Colloqium in the Vatican, t. 2, Florence 1982, s. 467-478.

Wyczawski H. E., Kalwaria Zebrzydowska. Historia klasztoru bernardynów i kalwaryjskich dróżek, Kalwaria Zebrzydowska 1987.

Wyszyński S., Kościół w stużbie Narodu, Rzym 1981.

Wyszyński S., Wielka Nowenna Tysiąclecia, Paris 1962.

Wyszyński S., Zapiski więzienne, Warszawa 1995, s. 147-156.

Zaremska H., Pielgrzymka jako kara za zabójstwo: Europa Środkowa XIII$X V$ w. w: Peregrinationes. Pielgrzymki w kulturze dawnej Europy, red. H. Manikowska, H. Zaremska, Warszawa 1995.

Zieliński Z., Kościót i naród w niewoli, Lublin 1995.

Zieliński Z., Kościół katolicki w Wielkim Księstwie Poznańskim w latach 1848-1965, Lublin 1973.

Zieliński Z., Kulturkampf, Encyklopedia Katolicka, t. 10, Lublin 2004, kol. 205-207.

Zieliński Z., Religia w narodowosocjalistycznej koncepcji społeczeństwa, w: Życie religijne w Polsce pod okupacja hitlerowska 1939-1945, red. Z. Zieliński, Warszawa 1982, s. 11-37.

Zieliński Z., Wielkopolskie pielgrzymki na Jasna Górę w czasie niewoli narodowej, „Studia Claramontana” 1(1981), s. 98-116.

Żaryn J., Dzieje Kościoła katolickiego w Polsce (1944-1989), Warszawa 2003.

Żaryn J., Kościót a władza w Polsce (1945-1950), Warszawa 1997. 